\title{
The loess-paleosol sequence at Monte Netto: a record of climate change in the Upper Pleistocene of the central Po Plain, northern Italy
}

\author{
Andrea Zerboni • Luca Trombino • Chiara Frigerio • \\ Franz Livio • Andrea Berlusconi • Alessandro M. Michetti • \\ Helena Rodnight $\cdot$ Christoph Spötl
}

Received: 27 February 2014 / Accepted: 12 June 2014

(C) Springer-Verlag Berlin Heidelberg 2014

\begin{abstract}
Purpose At the northern fringe of the Po Plain (northern Italy), several isolated hills exist, corresponding to the top of Late Quaternary anticlines. These hills were thoroughly surveyed for their soils and surficial geology, furnishing detailed archives of the palaeoenvironmental evolution of the area. A new, thick and complex loess-paleosol sequence, resting upon fluvial/fluvioglacial deposits, exposed in a quarry at the top of the Monte Netto hill was studied in detail to elucidate its significance.

Materials and methods Highly deformed fluvial and fluvioglacial deposits, probably of Middle Pleistocene age, are exposed in a clay pit at Monte Netto, underneath a 2- to 4-m-thick loess-paleosol sequence. A geopedological, sedimentological and micropedological investigation of the sequence shows a distinctive difference between the B horizons forming the sequence, while luminescence and radiocarbon age determinations and the occurrence of Palaeolithic lithic assemblages elucidate the chronology of the sequence.

Results and discussion The pedosedimentary sequence consists of several loess layers showing different degrees of alteration; loess deposition and weathering occurred,
\end{abstract}

Responsible editor: Fabio Scarciglia

A. Zerboni $(\bowtie) \cdot$ L. Trombino $(\bowtie) \cdot$ C. Frigerio

Dipartimento di Scienze della Terra "A. Desio", Università degli

Studi di Milano, Via Mangiagalli 34, 20133 Milan, Italy

e-mail: andrea.zerboni@unimi.it

e-mail: luca.trombino@unimi.it

F. Livio $\cdot$ A. Berlusconi $\cdot$ A. M. Michetti

Dipartimento di Scienza e Alta Tecnologia, Università dell'Insubria,

Via Valleggio 11, 22100 Como, Italy

H. Rodnight $\cdot$ C. Spötl

Institut für Geologie, Leopold-Franzens-Universität,

Innrain 52, 6020 Innsbruck, Austria according to optically stimulated luminescence (OSL) and AMS- ${ }^{14} \mathrm{C}$ dating as well as archaeological materials, during the Upper Pleistocene. The lower part of the section consists of strongly weathered colluvial sediments overlying fluvial and fluvioglacial sediments. A tentative model of the exposed profiles involves the burial of the anticline, which forms the core of the hill, by loess strata since Marine Isotopic Stage (MIS) 4 and their subsequent weathering (and truncation) during subsequent interstadials. The degree of weathering of buried B horizons increases from the top of the sequence toward the bottom, suggesting a progressive decrease in the intensity of pedogenesis. Finally, the highly rubified paleosol at the top of the hill is regarded as a buried polygenetic soil or a vetusol, developed near the surface since the Middle Pleistocene.

Conclusions The palaeopedological, geochronological and geoarchaeological analyses permit to define the phases and steps of development of the Monte Netto pedosedimentary sequence; the lower part of the sequence is dated to the MidPleistocene, whereas loess accumulation occurred between MIS 4 and MIS 2. Moreover, analyses help to clarify the climatic and environmental context of alternating glacial and interstadial phases, during which the sediments where deposited, deformed and weathered.

Keywords Geochronology · Late Quaternary · Loess/ paleosol $\cdot$ Micropedology $\cdot$ Pedosedimentary sequence · Po Plain

\section{Introduction}

In the framework of European terrestrial records of the Quaternary, loess complexes and interlayered paleosols (also known as pedocomplexes; Bronger and Sedov 2003) 
represent important pedosedimentary archives, which document the responses of continental ecosystems to glacial/ interglacial climate change. In Italy, and in particular in the Po Plain (northern Italy), the loess represents a key sedimentary record for palaeoenvironmental reconstructions (Cremaschi 1987, 1990a, 2004; Cremaschi et al. 2011). Many loess complexes have been described along the socalled Po Plain Loess Basin (PPLB; Amit and Zerboni 2013). These deposits are thinner and of smaller extent than other European loess outcrops, and for that reason, loess in northern Italy has been overlooked to some degree (Amit and Zerboni 2013) in comparison to the classical sequences of central and eastern Europe (Haase et al. 2007). Yet, loess in northern Italy was already described at the end of the nineteenth century (e.g. Capeder 1898; Viglino and Capeder 1898) and has been more extensively studied in the last few decades (e.g. Cremaschi 1987, 1990a, 2004; Orombelli 1990; Terhorst and Ottner 2003).

The term 'loess' refers to aeolian silty sediment, deposited under cold and arid environmental conditions (Smalley 1966; Cremaschi 1987; Pye 1987, 1995; Coudé-Gaussen 1990; Pecsi and Richter 1996; Smalley et al. 2001; Smalley and Jary 2005; van Loon 2006). If we consider northern Italy, the term 'loess' refers to silty sediments, which have been transported by wind; however, deposits are generally thin and affected by syn- and post-depositional weathering and soil formation that may mask their origin (Cremaschi 2004; Amit and Zerboni, 2013). In the PPLB (Fig. 1), loess occurs as thin sheets on dissected fluvial/fluvioglacial terraces and hills all along the margin of the Po Plain and on top of polygenetic paleosols developed in a variety of parent materials (Forno 1979; Busacca and Cremaschi 1998; Terhorst and Ottner 2003; Cremaschi 2004; Khün et al. 2006; Rellini et al. 2009; Livio et al. 2009). Sometimes, loess in the PPLB underwent colluviation (Cremaschi 1987, 2004; Mroczek 2013). Moreover, the loess is systematically associated with Middle
Palaeolithic artefacts, indicating that, in spite of the harsh environmental conditions, at that time the Po Plain was host to an ecosystem suited for human life (Cremaschi 1990a, 2004).

A well-preserved loess sequence in the PPLB is the Val Sorda sequence (Cremaschi 1990a; Ferraro 2009), where a thick cap of glacial sediments prevented intense pedogenesis. The most complex loess sequence, however, was recently discovered in a clay pit at the top of Monte Netto. In this paper, we discuss the palaeoenvironmental significance of the Monte Netto loess sequence and intercalated paleosols, integrating pedosedimentary data, optically stimulated luminescence (OSL) and AMS- ${ }^{14} \mathrm{C}$ dates. Paleosols interlayered in the sequence recorded the alternation between cold and interstadial periods during the Upper Pleistocene. A further peculiarity of this site is the occurrence of tectonic deformation in the form of folded and faulted loess and paleosol horizons (Livio et al. 2009, 2012); these tectonic deformations are dealt with in more detail in a companion paper. Finally, the palaeoenvironmental significance of this loess/paleosol sequence is discussed in the framework of the loess research at the southern and northern fringe of the Po Plain, reconstructing the episodes of the Upper Pleistocene aeolian activity in the PPLB and the main pedogenetic processes.

\section{Study area}

Monte Netto (Capriano del Colle, northern Italy) is an isolated hill (e.g. Desio 1965), located along a buried structural front of the central Southern Alps, facing the most external buried fronts of the northern Apennines beneath the Po Plain foredeep (e.g. Castellarin and Vai 1986; Castellarin et al. 2006; Fantoni et al. 2004). As suggested by Desio (1965), the emergence of the hill is due to the recent growing of a fold related to a fault system composed of a main south-vergent

Fig. 1 Map of the Po Plain Loess Basin (modified from Cremaschi 1987) illustrating the distribution of the main loess deposits in northern Italy; the localities cited in the text are also reported. Key: 1 Pre-Quaternary rocks; 2 Late Pleistocene and Holocene alluvial plain; 3 present-day coastline; 4 present-day $100-\mathrm{m}$ bathymetric line; 5 moraine systems; 6 loess deposits on fluvial and fluvioglacial deposits, moraine ridges and isolated hills; 7 loess on karst plateau; 8 direction of dominant winds during loess sedimentation

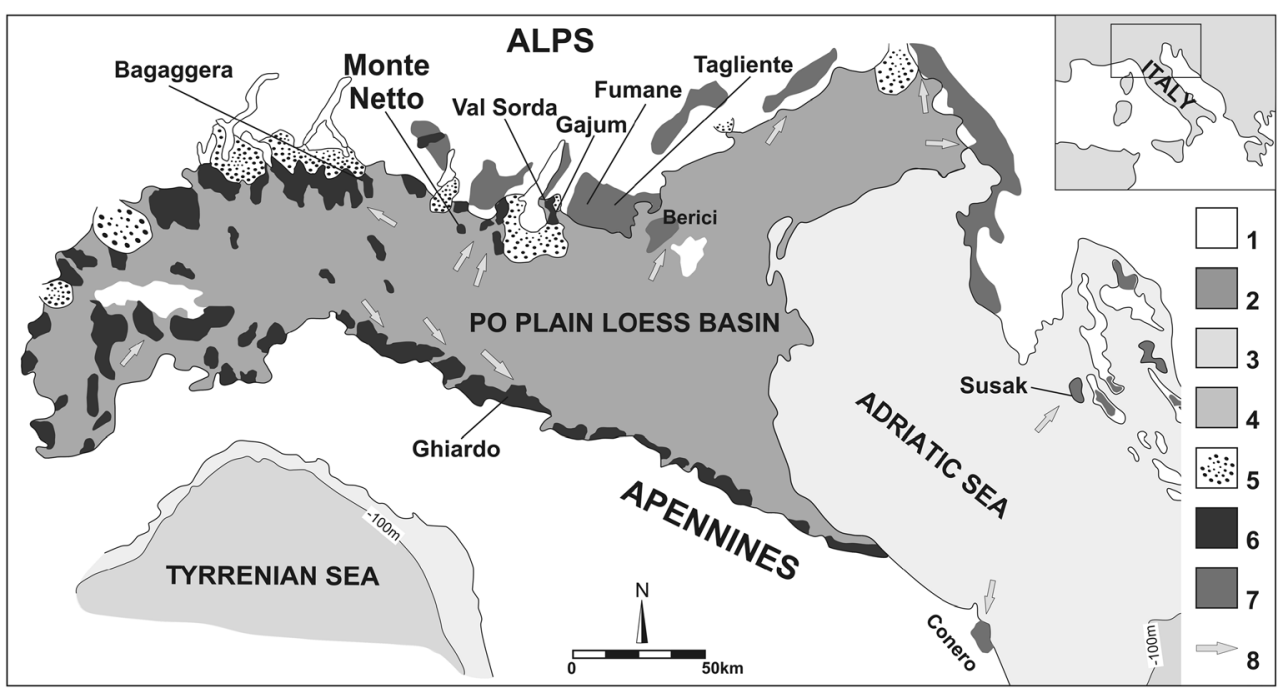


forethrust and an associated high-angle backthrust (Livio et al. 2009, 2012).

The Monte Netto hill is almost rectangular in shape $(5-\mathrm{km}$ long and 2-km wide), trending N110 and standing ca. $30 \mathrm{~m}$ above the surrounding alluvial plain, and is deeply eroded on its sides. The alluvial plain corresponds to a vast outwash fan, developed during the Last Glacial Maximum (LGM) by a meltwater channel network (e.g. Baroni and Cremaschi 1986; Marchetti 1996) that was subsequently incised by streams. The top of the hill exposes a gently folded sequence of Lower to Middle Pleistocene fluvial sediments (floodplain environment); younger fluvial sediments (Middle to Upper Pleistocene) onlap the hill on both sides (Livio et al. 2009). The oldest outcropping sediments are greenish-grey fine sands, with abundant shell remains, tentatively correlated to similar sediments, 0.89 Myr old, drilled in the Ghedi core (Carcano and Piccin 2002; Scardia et al. 2006), ca. $80 \mathrm{~m}$ below the surface and $10 \mathrm{~km}$ from the site. At the top, in a clay quarry, a moderately developed loess deposit, overlying a deeply weathered red paleosol, was described by Cremaschi (1987) and attributed to the Upper Pleistocene.

According to the map of pedolandscapes of Lombardia 1:250'000 (ERSAL 2001), in the area of Monte Netto, soils are mostly classified as Haplic, Chromic, Cutanic Luvisols (WRB 2006) or Typic (with Oxyacquic) Hapludalfs or Typic/ Mollic Paleudalfs (Soil Survey Staff 2010).

\section{Materials and methods}

The Monte Netto hill area was intensively surveyed in order to reconstruct the Middle to Upper Pleistocene geomorphological and sedimentological evolution of the area; the most significant and complex pedosedimentary sequence, located in the area of the Danesi clay quarry, was chosen for detailed palaeopedological investigations. A detailed field survey of the quarry area was conducted, which included mapping of the stratigraphic units both in section and in plan view. Also, a trench was dug at the base of the exposed quarry wall. The sequence exposed along a hundred metre long front comprised up to ca. $8 \mathrm{~m}$ of terrestrial sediments, whose top $(\leq 4 \mathrm{~m})$ consists of a loess deposit interlayered with paleosols with different degrees of maturity. The palaeopedological investigation included (i) a description of the sequence, (ii) sampling for pedological and heavy mineral analyses, (iii) oriented and undisturbed sampling for micropedological analyses and (iv) sampling for luminescence and radiocarbon dating.

Field descriptions and horizon designations were according to the internationally accepted guidelines proposed by FAO (2006). The soil horizons were grouped into pedostratigraphic levels (PLs), namely a set of horizons formed from parent materials having the same origin and age (Costantini and
Priori 2007). Generally speaking, paleosols can rarely be classified with accuracy (Nettleton et al. 1998; Krasilnikov and Calderón 2006; Zerboni et al. 2011) according to the international soil classification systems (e.g. FAO-UNESCO 1971; FAO 1998; Soil Survey Staff 1999, 2010; WRB 2006), and specific pedologic parameters should be considered in classification (James et al. 1998; Nettleton et al. 2000; Krasilnikov and Calderón 2006). In fact, paleosol classification requires the identification of those key attributes in modern soils that have preservation potential following burial, diagenesis and erosion events. Nevertheless, most of the key soil attributes in modern soils have a low potential of being preserved without major modification or even destruction (James et al. 1998; Zerboni et al. 2011). Notwithstanding that, we tried to find analogies between the described B horizons of the paleosols and modern soils categories as defined in the international classification systems (WRB 2006; Soil Survey Staff 2010).

Samples for laboratory analyses (bulk samples and blocks) were collected from the most representative B horizons of each pedostratigraphic level (PL1 to PL5). Additionally, an undisturbed block was extracted from the dark red buried paleosol at the top of the anticline of the Monte Netto hill for micropedological investigation; this paleosol is defined as PL0, even if it does not match the definition of pedostratigraphic level sensu Costantini and Priori (2007), but should be regarded as a buried polygenetic soil. The comparison between micromorphological features seen in PLO and those in the B horizons of the main sequence helped in understanding the evolution of the pedosedimentary sequence.

Soil samples were air dried and the particle size distribution was analysed by sieving the fraction $>63 \mu \mathrm{m}$, while the proportion of fine fraction $(<63 \mu \mathrm{m})$ was determined by the aerometer method (Gale and Hoare 1991). Heavy minerals were separated from the fine sand fraction $(63-125 \mu \mathrm{m})$ using a sodium metatungstate solution (density $2.9 \mathrm{~g} / \mathrm{cm}^{3}$ ) after removal of iron coatings through treatment with oxalic acid and carbonate coatings with hydrochloric acid (18\%) (Gale and Hoare 1991). The separated heavy minerals were mounted on slides using Canada balsam (refractive index $n=1.55$ ), and a minimum of 250 grains were identified and counted using a polarising microscope (Parfenoff et al. 1970; Mange and Maurer 1992).

Thin sections $(5 \times 9 \mathrm{~cm})$ were made after consolidation according to standard methods (Murphy 1986). For micromorphological study of thin sections, a petrographic microscope was employed (Leica Laborlux 12pol) with an Olympus C4040 digital camera. Thin sections were examined under plane-polarized light (PPL), cross-polarized light (XPL) and oblique incident light (OIL). The terminology of Bullock et al. (1985) and Stoops (2003) was used for thin section description, and some concepts of Brewer (1964) were taken 
into account. The concepts discussed by Stoops et al. (2010) greatly aided the interpretation of most of the pedofeatures.

Age control on the sequence was obtained by radiocarbon (AMS- ${ }^{14} \mathrm{C}$ ) and OSL dating. Six samples (three OSL and thee ${ }^{14} \mathrm{C}$ ) were dated. The retrieval of a comprehensive lithic assemblage belonging to a Middle Palaeolithic cultural horizon also helped in the chronological assessment of the phase of loess deposition and soil formation.

Samples for OSL analysis were prepared in the laboratory at Innsbruck. Approximately, $20 \mathrm{~g}$ of each sample was used for water content measurements and dosimetric analyses. The remainder was prepared for OSL analysis following the standard techniques proposed by Wintle (1997): initial pretreatment with $10 \% \mathrm{HCl}$, followed by 20 volumes of $\mathrm{H}_{2} \mathrm{O}_{2}$ (6\% solution) to remove carbonates and organic matter prior to dry sieving; after that, $1 \mathrm{mg}$ of the 4-11-m size fraction was obtained by settling following Stokes' law for analysis. The cosmic dose rate was estimated for each sample using the depth of overburden and the geomagnetic latitude (Prescott and Hutton 1994), assuming that the overlying sediment accumulated rapidly following deposition, making a correction for changing overburden thickness unnecessary. Sampling location at $10.1^{\circ} \mathrm{N}$ and $45.5^{\circ} \mathrm{E}$ and an elevation of $118 \mathrm{~m}$ a.s.l. were used as standard. The water content for each sample was measured in the laboratory and calculated as the mass of water divided by the mass of dry sediment, multiplied by 100 ; the containers that the samples were collected in were airtight, and thus the water content measured in the laboratory was close to the field value. The dose rate was calculated on the basis of the measured water content value with an error of $\pm 5 \%$. The luminescence analysis was undertaken using the double single-aliquot regenerative-dose (SAR) protocol with a preheat of $220^{\circ} \mathrm{C}$ for $10 \mathrm{~s}$ and a cut heat of $160{ }^{\circ} \mathrm{C}$ (Banerjee et al. 2001; Roberts and Wintle 2001). The De values were obtained from the blue LED-stimulated measurements (based on the quartz component of the polymineral fine-grain mixture). The De was measured for 24 aliquots of samples 8/CC01-03. From the De dataset of 24 values for each sample, the burial dose was calculated using the Central Age Model (Galbraith et al. 1999). The dose rates were calculated using the conversion factors of Adamiec and Aitken (1998) using the programme ADELE (Kulig, 2005) and using an alpha effectiveness value for quartz of $0.03 \pm 0.01$ (Mauz et al. 2006).

Finally, sediment samples were collected for AMS- ${ }^{14} \mathrm{C}$ dating in order to obtain radiometric age constraints for the upper part of the pedosedimentary sequence. The analyses were performed at the CEDAD Laboratory (Lecce, Italy) on the total organic fraction after removing contaminants by acid-base-acid treatment. The dates were calibrated $(2 \sigma$ range) using Calib 7.0 software (Stuiver et al. 2013) and INTCAL13 (Reimer et al. 2013).

\section{Results}

\subsection{Field characterization}

The pedosedimentary sequence exposed at Monte Netto is complex (Fig. 2) and along the quarry front the thickness of
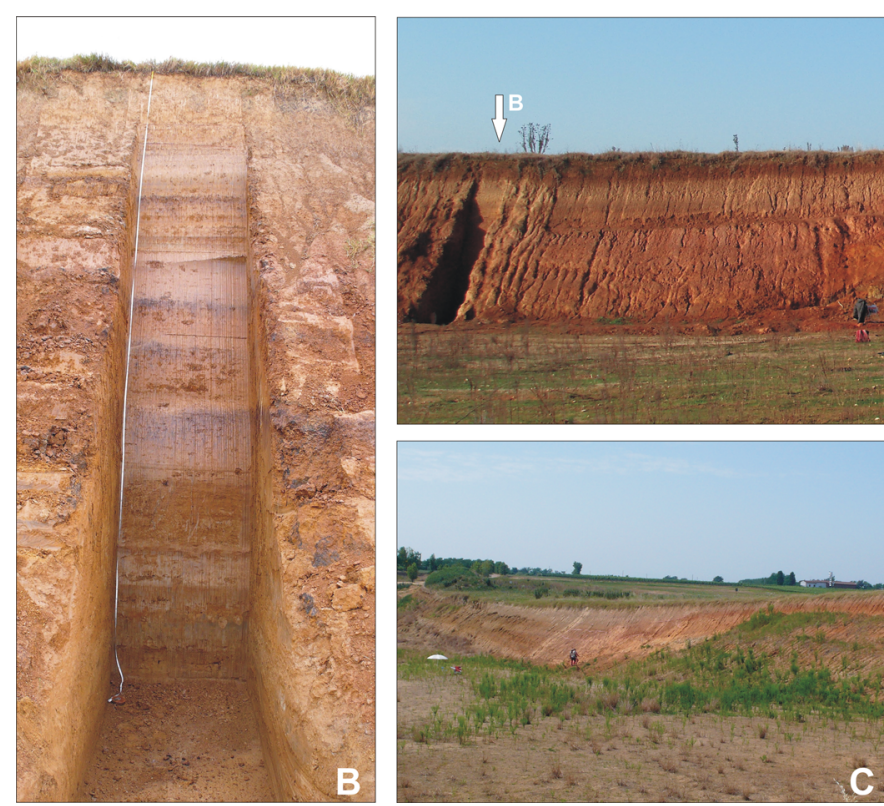

Fig. 2 Exposures at Monte Netto. a The central part of the section, which includes loess, paleosols and fluvio/fluvioglacial sediments forms an anticline (anticline crest is on the right); the arrow indicates the thickest sequence. b Main profile investigated in this study, located at the southern fringe of the quarry, and drawn in Fig. 3. c General view of the quarry; note the red paleosol at the top of the anticline (PL0). d Brittle, secondary, fold-related faulting, dislocating loess strata and paleosols in the central part of the anticline (Livio et al. 2009) 
each pedostratigraphic level and soil horizon differs greatly. The topographic relief, resulting from progressive growth of an anticline, acted as a barrier and allowed the formation of a syngrowth accommodation space for deposition of thick strata of loess that display a typical fill-to-the-top sedimentary architecture, characterized by pinching-out strata onlapping on onefold flank (Livio et al. 2009, 2012). The bedrock of the hill consists of a complex sequence of fluvial and fluvioglacial sediments that vary in texture and sedimentary facies and were deposited, folded and uplifted in the Pleistocene into the present anticline. At the core of this anticline, fluvial and fluvioglacial sediments occupy most of the exposure; in this sediments, a dark red paleosol occurs, buried beneath a thin loess cover. Meanwhile, the southern part of the quarry front displays a sequence of loess and paleosols up to $4 \mathrm{~m}$ thick covering a dark red paleosol developed in both colluvial sediments and fluvial to fluvioglacial deposits. Moreover, the central part of the exposure was deformed and displaced by several seismic events dated to the Upper Pleistocene (Livio et al. 2012) that caused the formation of a system of normal faults (e.g. a gravity graben depression; Fig. 2), displacing preexisting pedostratigraphic levels (Livio et al. 2009).

As shown in Fig. 2, the thickness of the loess/paleosols sequence is greater in the southern part of the quarry front and a profile was sampled there (Fig. 3). From a pedological point of view, the section can be divided into several B horizons, which developed in different parent materials and were affected by specific pedogenetic processes (field descriptions are in Table 1). Five pedostratigraphic levels are distinguished on the basis of the properties of their parent material; the horizons of each PL show an intense illuviation of clay and an increase of $\mathrm{Fe}-\mathrm{Mn}$-bearing pedofeatures toward the bottom, where a horizon rich in $\mathrm{Fe}-\mathrm{Mn}$ nodules is present. From the top of the sequence, PL1 consists, below the Ap horizon, of silt loamy $\mathrm{Bt}(\mathrm{x}), \mathrm{Bt}$ and $\mathrm{Btc}$ horizons with a platy to massive structure, very compact and light coloured; PL1 ends with a Bc horizon. The $\mathrm{Bt}(\mathrm{x})$ horizon can be interpreted as a sort of fragipan horizon (Assallay et al. 1998; Soil Survey Staff 2010). A further thin sequence of $\mathrm{B}$ horizons (2Bt and $2 \mathrm{Bc}$ ) follows, displaying a higher degree of clay illuviation and a darker colour; this sequence corresponds to pedostratigraphic level PL2. Pedostratigraphic level PL3 also consists of a sequence of silty clay loam to silty clay B horizons, dark brown to yellowish red in colour and displaying a downward increase in pedofeatures related to clay illuviation (3Bt1, 3Bt2, 3Bt3). A further $3 \mathrm{CBt}$ horizon shows evidence of clay illuviation, but its texture is more silty. $\mathrm{Fe}-\mathrm{Mn}$ coatings and nodules also increase with depth, reaching a maximum in the $3 \mathrm{Cc}$ horizon. The horizons 4Bt and 4Bc are developed in a slightly coarser parent material but exhibit a high degree of clay mobilization and accumulation of $\mathrm{Fe}-\mathrm{Mn}$ oxi-hydroxides; these horizons constitute the pedostratigraphic level PL4. Finally, the lowermost part of the sequence (pedostratigraphic level PL5) is

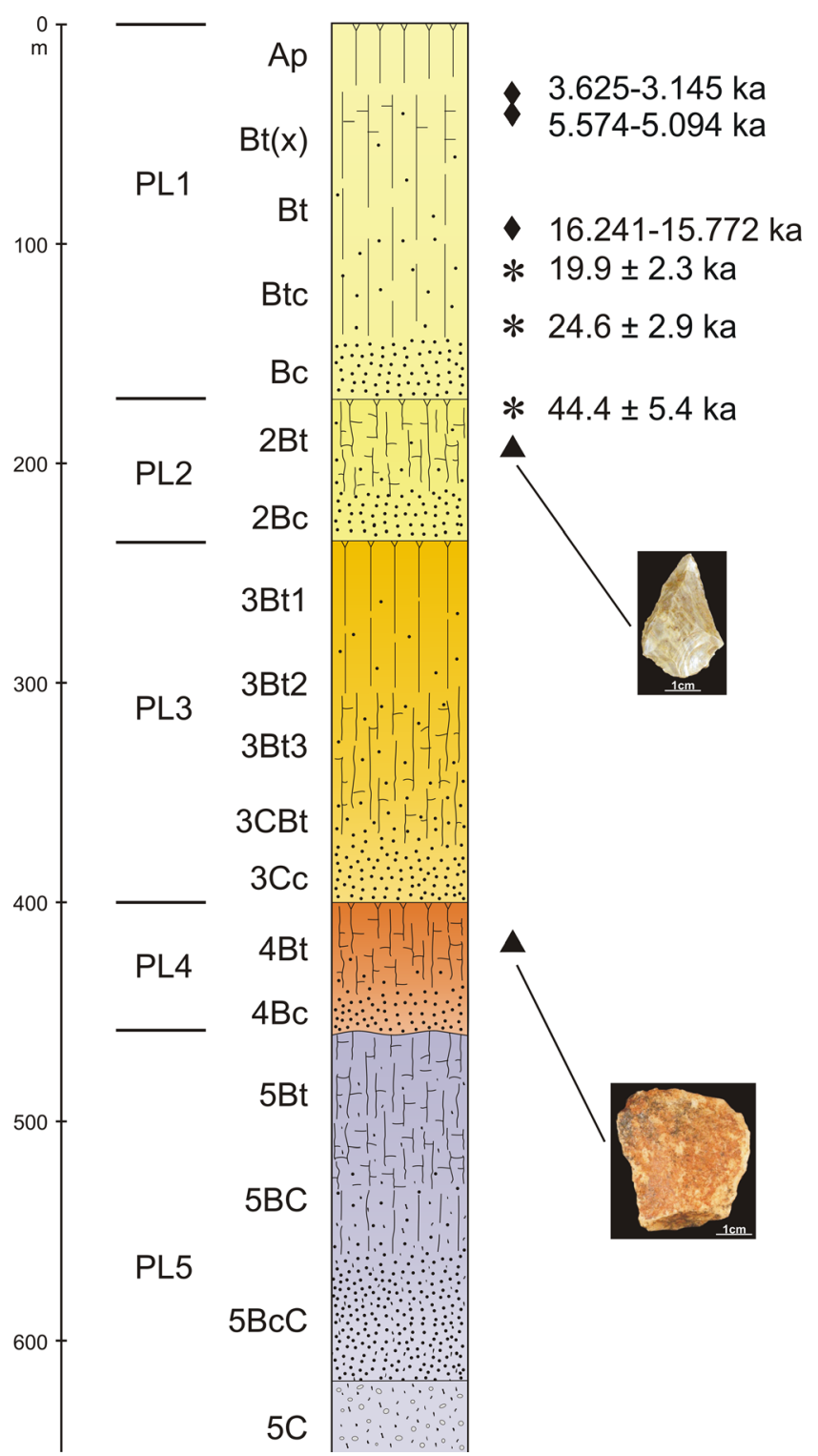

Fig. 3 The section described at Monte Netto indicating the distribution of soil horizons and the main pedostratigraphic levels. The position of OSL and AMS- ${ }^{14} \mathrm{C}$ dating results are also indicated. Black triangles represent the stratigraphic position of the archaeological finds; the upper one is the position of Mousterian lithics (the inset shows a Mousterian point), whereas the lower one indicates non-Levallois artefacts (inset shows a large quartzite flake - notice that it is coated by red illuvial clay)

represented by fluvial/fluvioglacial sediments, which are slightly weathered at their top.

\subsection{Dating the sequence}

OSL and radiocarbon dating results suggest that the upper pedostratigraphic levels of the exposure developed in loess from the Upper Pleistocene to the Holocene (Tables 2, 3 and 4). OSL samples collected from the lower part of the loessial PL1 level yielded an age between 19.9 and $24.6 \mathrm{ka}$, while a sample collected within the loess/paleosol PL2 yielded an age 
Table 1 Field properties of the main section at Monte Netto; colours are according to Munsell (1994)

\begin{tabular}{|c|c|c|c|c|}
\hline Horizon & Depth $(\mathrm{cm})$ & Description & $\begin{array}{l}\text { Pedostratigraphic } \\
\text { level }\end{array}$ & $\begin{array}{l}\text { Parent } \\
\text { material }\end{array}$ \\
\hline Ap & $0-30$ & $\begin{array}{l}\text { Silt loam; light yellowish brown (10YR 6/4); very weakly developed fine platy structure; } \\
\text { friable; medium and fine common pores; very few, small Fe-Mn concretions; gradual } \\
\text { lower boundary }\end{array}$ & PL1 & Loess \\
\hline $\operatorname{Bt}(\mathrm{x})$ & $30-60$ & $\begin{array}{l}\text { Silt loam; very pale brown }(10 \mathrm{YR} 8 / 3) \text {; few yellow coarse mottles }(10 \mathrm{YR} 8 / 6) \text {; weak fine } \\
\text { platy structure to massive structure; slightly firm; few small pores; very few, small Fe- } \\
\text { Mn nodules; few clay coatings; gradual lower boundary }\end{array}$ & PL1 & Loess \\
\hline $\mathrm{Bt}$ & $60-90$ & $\begin{array}{l}\text { Silt loam; yellow (10YR 7/8); coarse mottles very pale brown (10YR 8/3); weak fine platy } \\
\text { structure; slightly firm; common small pores; few, small Fe-Mn nodules; common clay } \\
\text { coatings; gradual lower boundary }\end{array}$ & PL1 & Loess \\
\hline Btc & $90-140$ & $\begin{array}{l}\text { Silt loam; brownish yellow (10YR 6/8); common mottles very pale brown }(10 \mathrm{YR} 8 / 3) \text {; } \\
\text { weakly developed medium prismatic to platy structure; moderately firm; few, small } \\
\text { pores; few, small Fe-Mn concretions increasing toward the bottom; few clay coatings; } \\
\text { gradual lower boundary }\end{array}$ & PL1 & Loess \\
\hline $\mathrm{Bc}$ & $140-170$ & $\begin{array}{l}\text { Silt loam; very dark brown }(10 \mathrm{YR} 2 / 2) \text {; massive; abundant }(60-80 \%) \text { coarse to fine } \mathrm{Fe}- \\
\text { Mn nodules (up to } 1 \mathrm{~cm}) \text { in the clay matrix; firm; few small pores; abrupt lower } \\
\text { boundary }\end{array}$ & PL1 & Loess \\
\hline $2 \mathrm{Bt}$ & $170-210$ & $\begin{array}{l}\text { Silt loam; yellowish brown (10YR 5/4); common mottles very dark grayish brown (10YR } \\
\text { 3/2); subangular blocky structure; firm; very few fine Fe-Mn nodules; common clay } \\
\text { coatings; very few small pores; gradual lower boundary }\end{array}$ & PL2 & Loess \\
\hline $2 \mathrm{Bc}$ & $210-230$ & $\begin{array}{l}\text { Silt loam; very dark brown (10YR 2/2); massive; abundant (60-80 \%) coarse to fine } \mathrm{Fe}- \\
\text { Mn nodules (up to } 1 \mathrm{~cm} \text { ) in the silty clay matrix; yellow ( } 2.5 \mathrm{Y} 7 / 8) \text { matrix; firm; few } \\
\text { small pores; abrupt lower boundary }\end{array}$ & PL2 & Loess \\
\hline 3Bt1 & $230-280$ & $\begin{array}{l}\text { Silty clay loam; brown ( } 7.5 \mathrm{YR} 4 / 4) \text { to strong brown }(7.5 \mathrm{YR} 5 / 6) \text {; common coarse mottles, } \\
\text { brownish yellow (10YR 6/8) to olive yellow ( } 2.5 \mathrm{Y} 6 / 8) \text {; angular blocky structure; firm; } \\
\text { few small pores; common clay coatings; gradual lower boundary }\end{array}$ & PL3 & Loess \\
\hline $3 \mathrm{Bt} 2$ & $280-310$ & $\begin{array}{l}\text { Silty clay loam; brown ( } 7.5 \mathrm{YR} 4 / 4) \text { to strong brown }(7.5 \mathrm{YR} 5 / 6) \text {; common coarse mottles } \\
\text { brownish yellow (10YR 6/8) to olive yellow ( } 2.5 \mathrm{Y} 6 / 8) \text {; angular blocky structure; firm; } \\
\text { few small pores; very common clay coatings; gradual lower boundary }\end{array}$ & PL3 & Loess \\
\hline $3 \mathrm{Bt} 3$ & $310-340$ & $\begin{array}{l}\text { Silty clay; brown (7.5YR 4/4); common coarse mottles brownish yellow (10YR 6/8) to } \\
\text { olive yellow ( } 2.5 \mathrm{Y} 6 / 8) \text {; angular blocky structure; firm; very few small pores; very } \\
\text { common clay coatings; gradual lower boundary }\end{array}$ & PL3 & Loess \\
\hline $3 \mathrm{CBt}$ & $340-380$ & $\begin{array}{l}\text { Silt loam; brown ( } 7.5 \mathrm{YR} 4 / 4) \text { to strong brown (7.5YR 5/6); common mottles black (5YR } \\
\text { 2.5/1) to dark reddish brown (5YR 2.5/2); angular blocky structure; firm Fe-Mn } \\
\text { coatings; few Fe-Mn nodules; few small pores; gradual lower boundary }\end{array}$ & PL3 & Loess \\
\hline $3 \mathrm{Cc}$ & $380-400$ & $\begin{array}{l}\text { Silt; very dark brown }(10 \mathrm{YR} 2 / 2) \text {; massive; abundant }(60-80 \%) \text { coarse to fine } \mathrm{Fe}-\mathrm{Mn} \\
\text { nodules (up to } 1 \mathrm{~cm}) \text { in the silty-clayey matrix; brownish yellow (10YR 6/8) matrix; } \\
\text { firm; few small pores; abrupt lower boundary }\end{array}$ & PL3 & Loess \\
\hline $4 \mathrm{Bt}$ & $400-440$ & $\begin{array}{l}\text { Clay loam; yellowish red (5YR 4/6); common mottles black (5YR } 2.5 / 1 \text { ) to dark reddish } \\
\text { brown (5YR 2.5/2); subangular blocky structure; moderately firm; common clay } \\
\text { coatings; few to common Fe-Mn coatings; very few Fe-Mn fine nodules; few small } \\
\text { pores; gradual lower boundary }\end{array}$ & PL4 & Colluvium \\
\hline $4 \mathrm{Bc}$ & $440-460$ & $\begin{array}{l}\text { Clay loam; very dark brown (10YR } 2 / 2) \text { to dark reddish brown }(5 \mathrm{YR} 3 / 3) \text {; massive; } \\
\text { abundant }(60-80 \%) \text { coarse to fine Fe-Mn nodules (up to } 1 \mathrm{~cm}) \text { in the silty clay matrix; } \\
\text { reddish brown ( } 5 \text { YR } 4 / 4) \text { silty matrix; firm; few small pores; abrupt lower boundary }\end{array}$ & PL4 & Colluvium \\
\hline $5 \mathrm{Bt}$ & $460-530$ & $\begin{array}{l}\text { Silty clay loam; strong brown (7.5YR 5/8); common mottles dark reddish brown (5YR } \\
\text { 3/4); subangular blocky structure; firm; few small pores; common Fe-Mn nodules; } \\
\text { common Fe-Mn coatings; common clay coatings; gradual lower boundary }\end{array}$ & PL5 & $\begin{array}{l}\text { Fluvial to } \\
\text { fluvioglacial }\end{array}$ \\
\hline $5 \mathrm{BC}$ & $530-570$ & $\begin{array}{l}\text { Clay loam; strong brown ( } 7.5 \mathrm{YR} 5 / 8 \text { ); common mottles dark reddish brown (5YR 3/4); } \\
\text { subangular blocky structure; firm; few small pores; very common Fe-Mn nodules } \\
\text { (locally abundant); very common Fe-Mn coatings; common clay coatings; gradual } \\
\text { lower boundary }\end{array}$ & PL5 & $\begin{array}{l}\text { Fluvial to } \\
\text { fluvioglacial }\end{array}$ \\
\hline $5 \mathrm{BcC}$ & $530-620$ & $\begin{array}{l}\text { Loam; very dark brown (10YR } 2 / 2) \text {; massive; abundant ( } 60-80 \%) \text { coarse to fine Fe-Mn } \\
\text { nodules in the silty clay matrix; strong brown ( } 7.5 \mathrm{YR} 4 / 6) \text { silty sandy matrix; firm; very } \\
\text { few calcium carbonate nodules; few small pores; abrupt lower boundary }\end{array}$ & PL5 & $\begin{array}{l}\text { Fluvial to } \\
\text { fluvioglacial }\end{array}$ \\
\hline $5 \mathrm{C}$ & $>620$ & $\begin{array}{l}\text { Sequence of unweathered sediments including strata of clay, silt, sand, coarse sand and fine } \\
\text { gravel; laminated to massive; very few calcium carbonate nodules; very few Fe-Mn } \\
\text { nodules; lower boundary not reached }\end{array}$ & PL5 & $\begin{array}{l}\text { Fluvial to } \\
\text { fluvioglacial }\end{array}$ \\
\hline
\end{tabular}


Table 2 Details of dosimetry calculations for samples from the Monte Netto section

\begin{tabular}{lllllllll}
\hline Sample name & $\begin{array}{l}\text { Pedostratigraphic } \\
\text { level }\end{array}$ & $\begin{array}{l}\text { Grain size } \\
(\mu \mathrm{m})\end{array}$ & $\begin{array}{l}\text { Water content } \\
(\%)\end{array}$ & $\begin{array}{l}\text { Potassium } \\
(\%)\end{array}$ & $\begin{array}{l}\text { Uranium } \\
(\mathrm{ppm})\end{array}$ & $\begin{array}{l}\text { Thorium } \\
(\mathrm{ppm})\end{array}$ & $\begin{array}{l}\text { Cosmic dose } \\
\text { rate (mGy/ka) }\end{array}$ & $\begin{array}{l}\text { Total dose rate } \\
(\mathrm{Gy} / \mathrm{ka})\end{array}$ \\
\hline $\mathrm{CC} 1$ & PL1 & $4-11$ & 9.5 & $1.99 \pm 0.10$ & $15.9 \pm 0.8$ & $4.5 \pm 0.2$ & $176 \pm 18$ & $7.01 \pm 0.83$ \\
$\mathrm{CC02}$ & PL1 & $4-11$ & 7.3 & $1.95 \pm 0.10$ & $16.6 \pm 0.8$ & $4.8 \pm 0.2$ & $176 \pm 18$ & $7.37 \pm 0.88$ \\
$\mathrm{CC03}$ & PL2 & $4-11$ & 6.3 & $1.65 \pm 0.08$ & $16.8 \pm 0.8$ & $4.9 \pm 0.2$ & $161 \pm 16$ & $7.22 \pm 0.89$ \\
\hline
\end{tabular}

${ }^{a}$ The total effective dose rate from the environment to quartz grains 4-11 $\mu \mathrm{m}$ in diameter was calculated taking into account the alpha efficiency factor

of c. $44 \mathrm{ka}$. Unfortunately, samples collected at greater depth in the early loess strata (along PL3) gave no results. Radiocarbon dating was performed on the organic fraction of three samples, collected at the top of the pedosedimentary sequence (PL1), at depths ranging from c. 0.4 to $1 \mathrm{~m}$. The deepest sample (CAP03) was dated at 13,313 \pm 75 BP (16.215.8 cal ka BP), while the upper samples were dated at $6,485 \pm$ 50 and 4,635 \pm 45 BP (7.5-7.3 and 5.6-5.1 cal ka BP).

Lithic artefacts recovered within the loess strata helped in the chronological assessment of loess deposition (Fig. 3). Some Palaeolithic flakes (raw materials: quartzite and flint) were found in the deepest red soil, within the 4Bt horizon of PL4. They do not present a clear Levallois technology and, on the basis of their similarity to other lithic assemblages described in residual red soils found at the top of the Monte Netto hill (Zorzi 1959; Cremaschi 1974), are attributed to a Lower/Middle Palaeolithic cultural horizon. The in situ recovery of these artefacts is confirmed by the absence of signs of post-sedimentary transport and by the occurrence of a thick red patina (coating of clay). Within the loess/paleosol complex of PL2, we found an assemblage of Middle Palaeolithic artefacts (raw material: flint), which, on the basis of a preliminary analysis, are attributed to the Mousterian phase. This attribution fits well with the available OSL dating and suggests a synchronicity between loess deposition in the PPLB and the Mousterian frequentation of the Po Plain (by hunter groups), as suggested by previous authors (Cremaschi and Christopher 1984; Cremaschi 1987; Peresani et al. 2008; Cremaschi et al. 2011, in press). Mousterian artefacts at Monte Netto have sharp edges, indicating that they did not undergo any postdepositional transport, and often they display glossy surfaces, due to aeolian abrasion by quartz grains, typical of lithics recovered within loess (Cremaschi and Christopher 1984). Therefore, they are considered as in situ.

\subsection{Grain size analysis}

Grain size analyses (Fig. 4) were carried out on the Monte Netto pedosedimentary sequence to characterize the fine earth $(<2 \mathrm{~mm})$ fraction, while the horizons strongly cemented by pisolithic concretions were not analysed.

From the top to the base of the sequence, the cumulative grain size distribution curves of the pedostratigraphic level PL1 show characteristic sigmoidal patterns. Curves are unimodal and well-sorted, with a strong positive skewness and the sand and silt values are about $80 \%$. In the pedostratigraphic level PL2, the sampled horizons also show well-sorted asymmetric (positive skewness) sigmoidal curves but with sand and silt values of about $70 \%$. The third pedostratigraphic level PL3 still shows well-sorted asymmetric (positive skewness) sigmoidal curves, but different sand and silt values, ranging from about $55 \%$ (3Bt3 horizon) to about $75 \%$ (3CBt horizon), apparently depending on the extent of illuviation. The PL4 and PL5 pedostratigraphic levels show completely different grain size distributions and poor to very poor sorting (the cumulative curve for the $5 \mathrm{C}$ horizon is almost straight) with some differences in the sand and silt values, ranging from about 65 to about $80 \%$.

\subsection{Heavy minerals}

Trends in the abundance of amphiboles and epidote allow us to subdivide the sequence into three main parts: the amount of amphiboles decreases sharply from the lower horizon of PL1, while epidote levels remain quite constant and decrease only in pedostratigraphic levels PL4 and PL5 (Table 5). The upper subdivision is even more evident (Table 6) when the heavy minerals are grouped according to three of the ten indicators defined by Garzanti and Andò $(2007 \mathrm{a}, \mathrm{b})$ : the minerals

Table 3 OSL ages for the Monte Netto section

\begin{tabular}{llllll}
\hline Sample name & Pedostratigraphic level & Number of aliquots & Burial dose $(\mathrm{Db})^{\mathrm{a}}(\mathrm{Gy})$ & Environmental dose rate $(\mathrm{Gy} / \mathrm{ka})$ & Age BP $(\mathrm{ka})$ \\
\hline $\mathrm{CC} 01$ & PL1 & 24 & $146 \pm 3$ & $7.37 \pm 0.88$ & $19.9 \pm 2.3$ \\
$\mathrm{CC0} 2$ & PL1 & 24 & $173 \pm 4$ & $7.01 \pm 0.83$ & $24.6 \pm 2.9$ \\
$\mathrm{CC03}$ & PL2 & 24 & $321 \pm 9$ & $7.22 \pm 0.89$ & $44.4 \pm 5.4$ \\
\hline
\end{tabular}

${ }^{a}$ Calculated using the central mean model 
Table 4 AMS- ${ }^{14} \mathrm{C}$ ages for the Monte Netto section; $2 \sigma$ range is calculated using Calib 7.0 (Stuiver et al. 2013), using the INTCAL13 calibration curve (Reimer et al. 2013)

\begin{tabular}{llllll}
\hline Sample name & Pedostratigraphic level & Depth $(\mathrm{cm}) \mathrm{v}$ & $\delta 13 \mathrm{C}(\%)$ & Uncal 14C age (years BP) & Cal 14C age $( \pm 2 \sigma)(\mathrm{ka} \mathrm{BP})$ \\
\hline CAP01 & PL1 & 40 & $-22.5 \pm 0.3$ & $4,635 \pm 45$ & $5.574-5.094$ \\
CAP02 & PL1 & 50 & $-28.0 \pm 0.3$ & $6,485 \pm 50$ & $7.483-7.287$ \\
CAP03 & PL1 & 100 & $-33.7 \pm 0.5$ & $13,313 \pm 75$ & $16.241-15.772$ \\
\hline
\end{tabular}

indicative of high-grade metasedimentary minerals (HgM index: staurolite, sillimanite, kyanite and andalusite), the ultrastable minerals (ZTR index: zircon, tourmaline and rutile) and the T\& index, which includes titanium-bearing minerals (titanite, anatase, brookite) and other minerals (apatite, mozanite, barite). All considered indexes show higher values starting from the PL2.

By grouping the heavy minerals in a ternary diagram (Fig. 5), it is possible to identify the differences in composition along the whole pedosedimentary sequence: the horizons of the pedostratigraphic level PL1 are placed close to the amphiboles/epidote side, while samples of PL2 and PL3 are dispersed close to the epidote/zircon + tourmaline side not far from the epidote corner. Samples of the pedostratigraphic
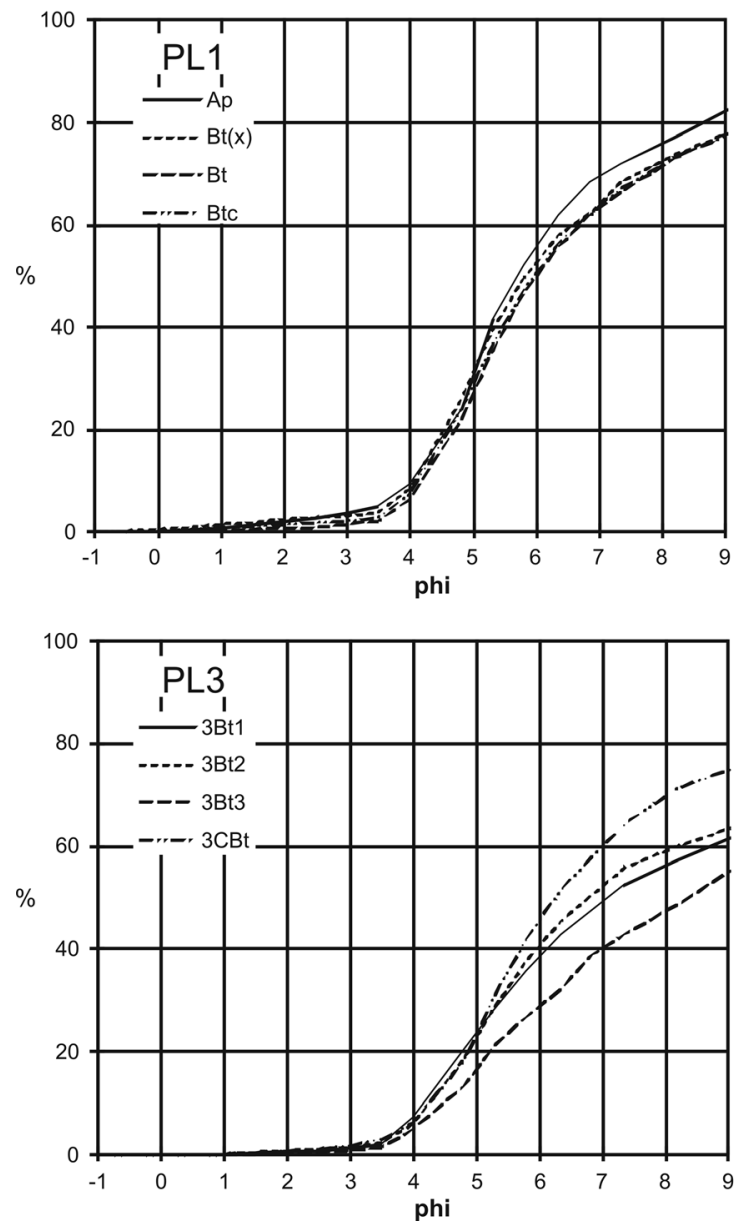

levels PL4 and PL5 are still distributed close to the epidote/ zircon + tourmaline side but not far from the zircon + tourmaline corner.

The distribution of heavy minerals is controlled by the characteristics of the parent material and the degree of weathering (Cremaschi, 1987). Considering our results, we postulate a main discontinuity between the composition of the parent material of the lower pedocomplexes developed in fluvial and fluvioglacial sediments (PL4 and PL5) and the heavy mineral assemblage of the PL1 to 3 . The origin of PL4 and PL5 is related to the occurrence of meltwater rivers from the central sector of the Italian Alps, while PL1 to 3 are related to loess deflated from the Po Plain, which was a deflation basin fed by rivers from the entire Alpine domain (Cremaschi,
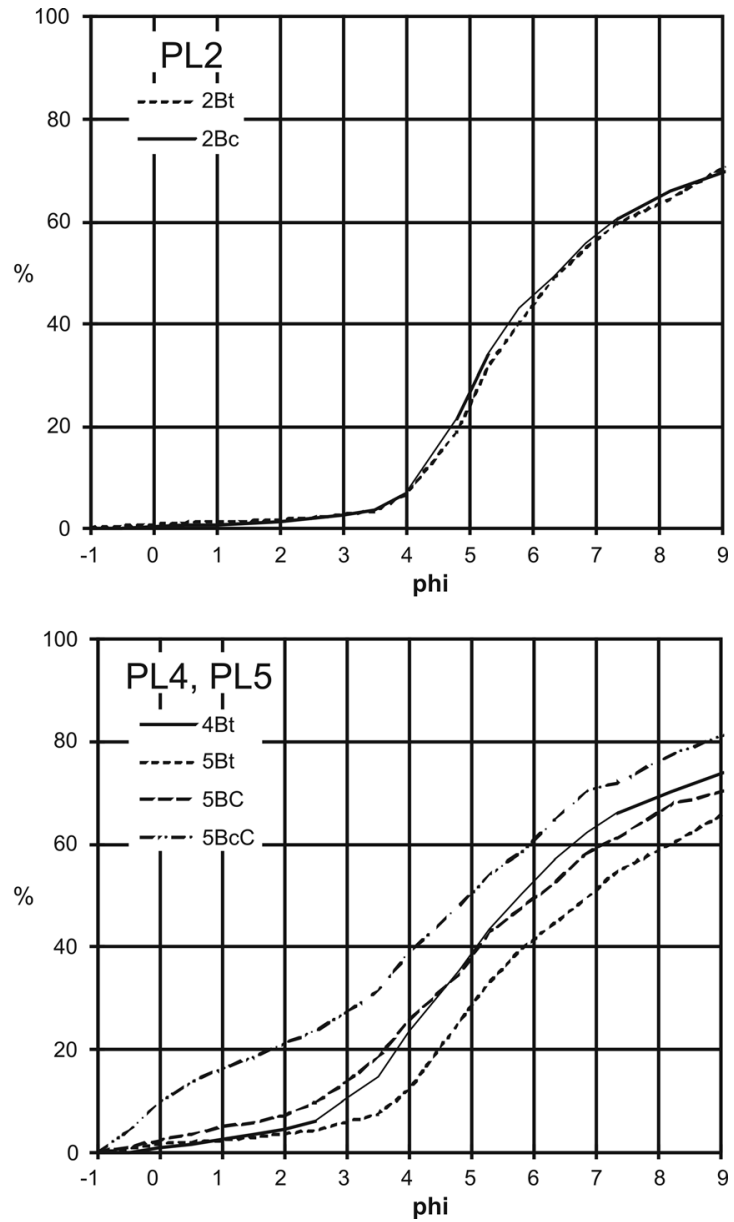

Fig. 4 Cumulative grain size curves of fine earth $(<2 \mathrm{~mm})$ from the pedological horizons described at Monte Netto; PLs are also indicated 
Fig. 5 Ternary diagram showing the heavy mineral distribution according to Durn et al. (2007)

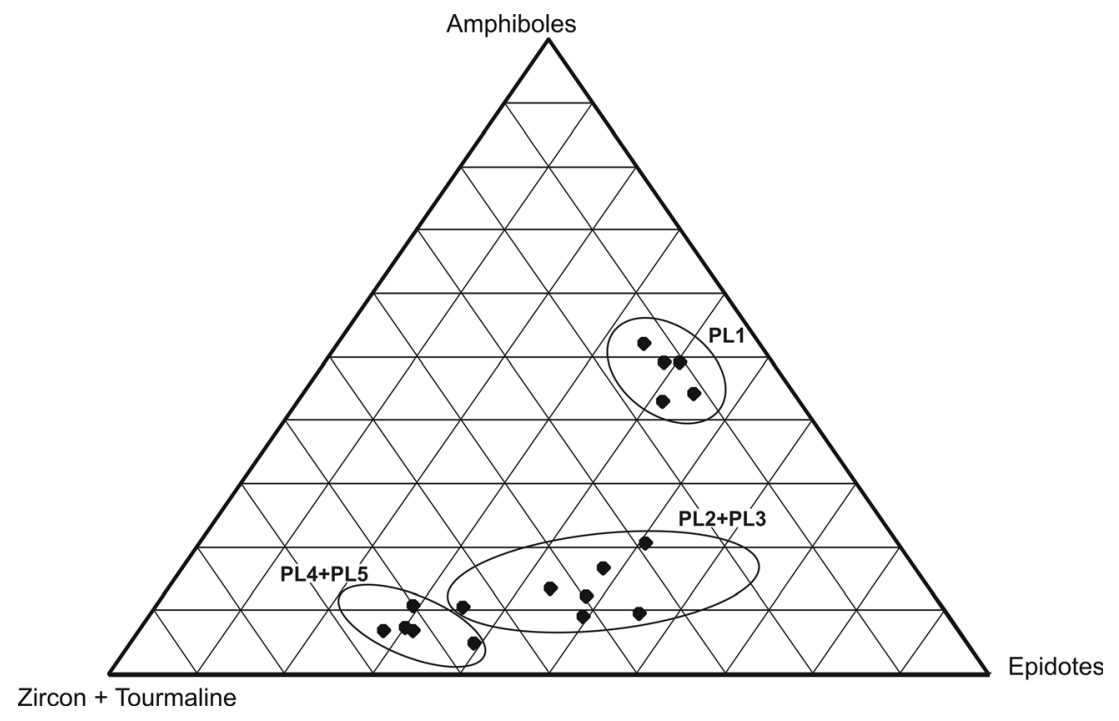

1987; Ferraro, 2009). A useful approach to describe the heavy mineral distribution and to evaluate the rate of weathering is to calculate the weathering indexes proposed by Brewer (1964), defined as zircon + tourmaline vs. pyroxenes + amphiboles, and by Cremaschi (1978), defined as zircon + tourmaline + titanium oxides vs. pyroxenes + amphiboles + epidotes. It should be stressed that the mineralogical heterogeneity of the parent material presented above does not allow a true quantitative comparison of the calculated indexes between horizons developed in different pedostratigraphic levels. For that reason, taking into account the main mineralogical discontinuities, the relationship between the degree of weathering and the heavy mineral assemblages can be summarized as follows:

- In the horizons pertaining to pedostratigraphic level PL1, both indexes show values close to 0 ; this means that mineralogical evidence of weathering is virtually absent.

- In the PL2 and PL3, whose heavy mineral compositions are very similar, both indexes (but mainly Brewer's) testify the presence of different degrees of weathering between the described horizons and indicate that the maximum intensity of weathering occurred in the $3 \mathrm{Bt} 2$ horizon.

- The heavy mineral compositions of PL4 and PL5 are very similar, but a mineralogical indicator for weathering is evident in the uppermost parts of each pedostratigraphic level (the 4Bt and 5Bt horizons); these horizons show the highest values of both indexes compared to the other horizons of the pedostratigraphic sequence.

\subsection{Thin-section micromorphology}

All thin sections show a porphyric $\mathrm{c} / \mathrm{f}$-related distribution (ranging from close to double-spaced) and a microstructure from massive (Fig. 6a and Table 7) to subangular blocky (Fig. 6b), depending on the frequency of planes. Moreover, the micromass generally shows rare to few depleted areas identified by colour, limpidity and b-fabric (Fig. 6b). The frequency of depletion areas together with the presence and nature of amorphous pedofeatures (sensu Bullock et al. 1985) is higher in samples from the pisolithic horizons (i.e. Btc, $2 \mathrm{Bc}$ and $4 \mathrm{Bc}$ ): recurrent coarse iron and manganese nodules (Fig. 6c), showing both sharp and diffuse boundaries, together with the presence of iron and manganese hypocoatings (Fig. 6d) and small nodules, are the micromorphological markers of those horizons.

Textural pedofeatures (sensu Bullock et al. 1985) increase the level of complexity of the described pedosedimentary sequence. From the top to the base:

- The pedostratigraphic level PL1 is characterized, in its upper part, by the presence of yellowish brown dusty clay coatings, sometimes laminated (Fig. 7a), while in the deeper part, it is characterized by the presence of orange, thin, limpid clay coatings and infillings (Fig. 7b), whose thickness increases with depth.

- In the pedostratigraphic level PL2, the most recurring textural pedofeatures are yellow clay coatings, limpid when thin (Fig. 7c) and layered when thick.

- The pedostratigraphic level PL3 displays three distinct textural pedofeatures, i.e. yellow-layered clay coatings, pale yellow clay intercalations (Fig. 7d) and rare fragments of red clay coatings (Fig. 7e).

- The pedostratigraphic level PL4 has only yellow clay coatings, thick and layered (Fig. 7f), sometimes thin.

To summarize, it is possible to state that the yellow-layered clay coatings are the most recurring textural pedofeatures in the deeper part of the pedosedimentary sequence, 


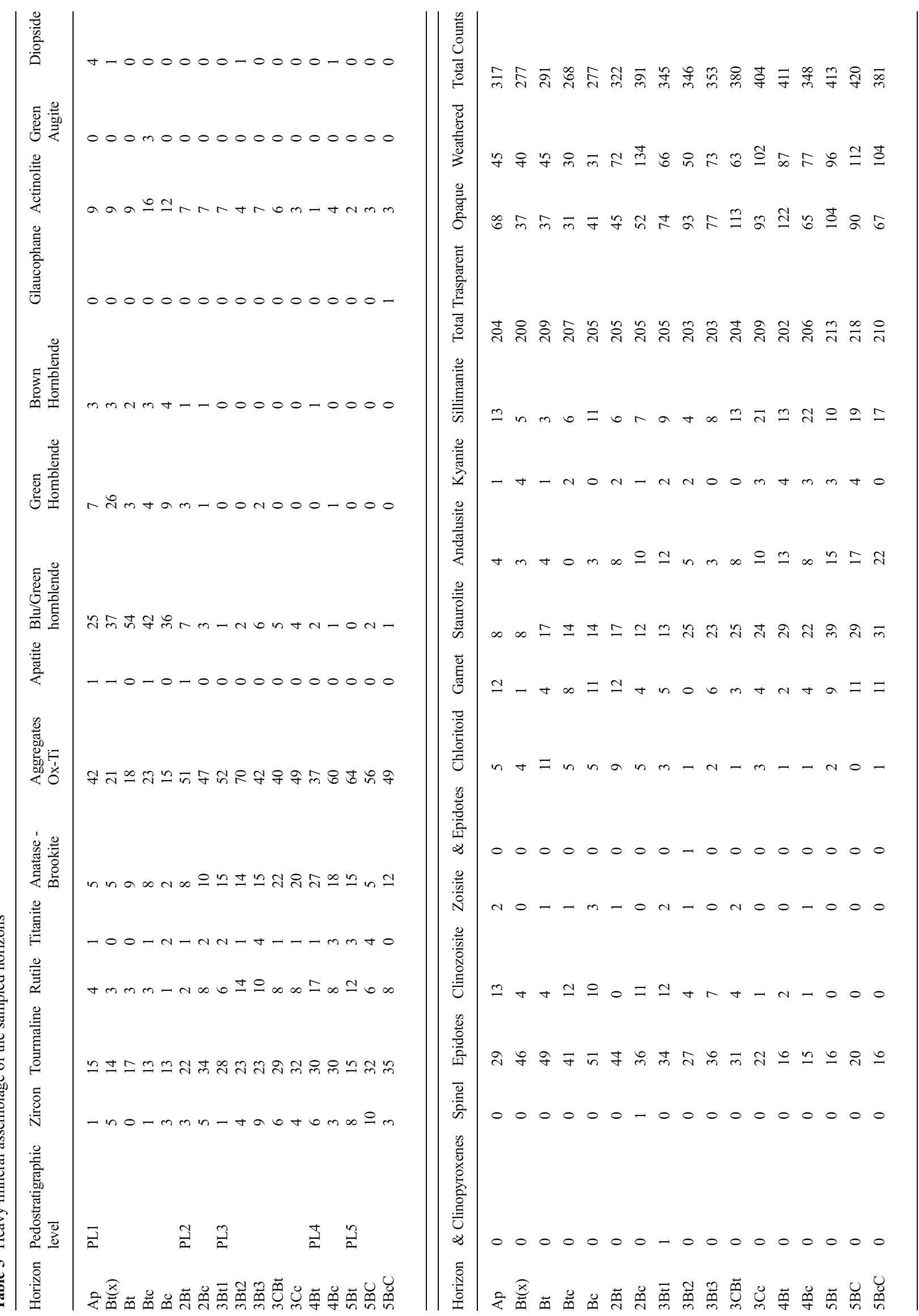


accompanied by various other textural pedofeatures in the different described layers (in particular, the red clay coatings), while the orange limpid clay coatings and the yellowish brown dusty clay coating are present only in the upper unit and in the surface horizon, respectively. Finally, the deeply weathered paleosol of PL0, sampled at the top of the anticline, shows the contemporary presence of the four main generations of textural pedofeatures, namely yellowish brown coarse infillings, orange thick limpid clay coatings, yellow clay coatings layered when thick and red fragments of clay coatings, underscoring its origin as a polygenetic soil (Bos and Sevink 1975) or vetusol (Cremaschi 1987).

\section{Discussion}

\subsection{Origin of parent material and soil-forming processes}

Taking into account the cumulative grain size distribution curves for each of the identified PLs (Fig. 4) and heavy minerals assemblags (Fig. 8), some key differences can be noticed, which allow us to separate them into three main groups. All of these groups of curves have been compared to the reference theoretical cumulative grain size distribution curves (Fig. 9), which were elaborated for fresh loess and weathered loess from the PPLB (Cremaschi 1987) in order to evaluate their degree of weathering. Curves from the upper pedostratigraphic levels (PL1, PL2, PL3) show sigmoid trends and asymmetric grain size distributions with a low sand content (below $10 \%$ ) and a clay fraction varying between 45 and $20 \%$. These curves fit well with the curves of Po Plain loess by Cremaschi (1987): they fall in the range between the fresh and weathered loess, with a slight predominance of the latter. Moreover, going from PL1 to PL3, the cumulative curves highlight a clear shift towards the theoretical curve representative for weathered loess. As a consequence, we conclude that the degree of weathering decreases from PL3 to PL1. Samples from the subsequent level PL4 also gave grain size distribution curves with a moderate clay content, but here the coarse fraction is well represented (above $20 \%$ sand). Therefore, the parent material of PL4 was not loess, and we interpreted it as a colluvium of older sediments (see below for a more detailed explanation of its origin). Finally, PL5 consists of sediment with a high sand content (up to $40 \%$ ). It corresponds to the upper part of the fluvial to fluvioglacial substrate of the hill. These main differences in the parent material are confirmed by the heavy mineral assemblage (Fig. 8). In fact, we can identify the same origin for the parent material of units PL4 and PL5, which fits well with the heavy mineral assemblage of fluvioglacial deposits of the Po Plain (Muttoni et al. 2003; Scardia et al. 2006). On the contrary, heavy minerals from PL1, PL2 and PL3 are rather different and comparable to those of loess deposits from northern Italy (Cremaschi 1987, 2004; Ferraro, 2009).

Field observations, laboratory analyses and micromorphological descriptions indicate that a number of soil-forming processes affected the parent material: pedoplasmation, rubification, clay translocation and hydromorphism are the main processes observed in the Monte Netto pedosedimentary sequence. These pedogenetic features are present in all the described pedostratigraphic levels, albeit to a different degree. Moreover, also inside each individual pedostratigraphic level, $\mathrm{B}$ horizons show a variable intensity of the pedogenetic processes. Each pedostratigraphic level corresponds to the deposition of a new parent material during a rhexistasy period (Erhart 1951) in which the protective vegetation cover was reduced or eliminated and erosion and accumulation phenomena took place. The rhexistasy periods are separated by biostasy phases (Erhart 1951), when climatic conditions were favourable for the development of vegetation protecting the soil from erosion and in which pedogenesis can play a major role, inducing the weathering of the earlier deposited parent material and intensifying illuviation phenomena. At Monte Netto, the biostasy periods promoted a moderate fersiallitic pedogenesis (Duchaufour 1983), characterized by pedoplasmation, which meant a decrease in silt content and an increase in clay content (Stoops et al. 2010), rubification (i.e. release of iron oxides leading to a redder colour), clay translocation (sensu Cremaschi 1987) and hydromorphy (Duchaufour 1983). The latter process was most likely triggered by water-logging induced by the occurrence of the impervious B horizons enriched in clay at the top of each pedostratigraphic level.

In the following section, the properties of the analysed horizons are compared in order to establish which pedogenetic processes acted on each parent material and to evaluate the intensity of pedogenesis.

- The pedostratigraphic level PL1 is only moderately weathered: the yellowish colour of the B horizons described in the field (10YR), their very homogeneous grain size distribution, which is comparable to moderately weathered loess of the Po Plain, and the heavy mineral assemblage dominated by weatherable minerals (e.g. amphiboles and epidote) suggest incipient pedogenesis. Moreover, micromorphological properties of PL1 suggest that the horizon was strongly affected by coarse clay illuviation, probably induced by recent tillage on the topsoil (agricutans, Brewer 1964; Jongerius 1983), while the presence of a pure to dusty, orange clay illuviation phase seems to indicate a previous phase of degradation with a discontinuous vegetation cover, as suggested by previous studies on paleosols developed in loess from France and Italy (Fedoroff and Goldberg 1982; Cremaschi 1987; Cremaschi et al. 1990). Finally, the amorphous 
Table 6 Heavy mineral indicators key elaborated according to Garzanti and Andò (2007a, b)

Horizon Pedostratigraphic level HGM index ZTR index T\& index

\begin{tabular}{|c|c|c|c|}
\hline \multicolumn{4}{|l|}{ PL1 } \\
\hline Ap & 26 & 20 & 49 \\
\hline $\mathrm{Bt}(\mathrm{x})$ & 20 & 22 & 27 \\
\hline $\mathrm{Bt}$ & 25 & 20 & 27 \\
\hline Btc & 22 & 17 & 33 \\
\hline $\mathrm{Bc}$ & 28 & 17 & 19 \\
\hline \multicolumn{4}{|l|}{ PL2 } \\
\hline $2 \mathrm{Bt}$ & 33 & 27 & 61 \\
\hline $2 \mathrm{Bc}$ & 30 & 47 & 59 \\
\hline \multicolumn{4}{|l|}{ PL3 } \\
\hline $3 \mathrm{Bt} 1$ & 36 & 35 & 69 \\
\hline $3 \mathrm{Bt} 2$ & 36 & 41 & 85 \\
\hline $3 \mathrm{Bt} 3$ & 34 & 42 & 61 \\
\hline $3 \mathrm{CBt}$ & 46 & 43 & 63 \\
\hline $3 \mathrm{Cc}$ & 58 & 44 & 70 \\
\hline \multicolumn{4}{|l|}{ PL4 } \\
\hline $4 \mathrm{Bt}$ & 59 & 53 & 65 \\
\hline $4 \mathrm{Bc}$ & 55 & 41 & 81 \\
\hline \multicolumn{4}{|l|}{ PL5 } \\
\hline $5 \mathrm{Bt}$ & 67 & 35 & 82 \\
\hline $5 \mathrm{BC}$ & 69 & 48 & 65 \\
\hline $5 \mathrm{BcC}$ & 70 & 46 & 61 \\
\hline
\end{tabular}

pedofeatures attest to the development of hydromorphic processes with depth.
- The pedostratigraphic level PL2 is only $60 \mathrm{~cm}$ thick, probably due to an erosional phase preceding the deposition of the overlying PL1 parent material. However, it appears more weathered than the overlying PL1, as is attested by the reddening of the micromass in thin section and the grain size distribution cumulative curves, which agree with those of weathered loess of the PPLB (Cremaschi 1987). As a general issue, the heavy mineral assemblage of PL2 may account for a slightly different mineralogy of the parent material with respect to the overlying PL1. Finally, yellow, limpid clay coatings and infillings observed in thin section also indicate a welldeveloped illuviation phase under a stable vegetation cover (Kühn et al. 2010), while amorphous pedofeatures testify, also in this level, to the development of hydromorphic processes with depth.

- The pedostratigraphic level PL3 reaches, in its top horizons, a greater level of weathering, as shown by the reddening of the micromass in thin section and by the grain size distribution cumulative curves, which are comparable to weathered (3Bt1 and 3Bt2 horizons) to strongly weathered (3Bt3 horizon) loess of the Po Plain. Further, the heavy mineral assemblages of PL3 and of the overlying PL2 are very similar. In this case, it is possible to compare the absolute values of the weathering indexes of both levels and to state that PL3 is clearly more weathered than PL2. Clay illuviation is also more developed than in the overlying pedostratigraphic levels, accounting for at least two distinct illuviation phases: an older phase attested by red fragments of clay coatings (i.e. papulas; Brewer 1964) without evident deformation (indicative of bioturbation; Stoops 1999) and a more recent illuviation,
Fig. 6 Photomicrographs of thin sections illustrating the microstructure and $\mathrm{Fe}-\mathrm{Mn}$ related pedofeatures. a Massive microstructure of the $2 \mathrm{Bc}$ horizon (PPL); b subangular blocky microstructure of the $3 \mathrm{Bt} 3$ horizon (the arrows indicate a depleted area (PPL)); c Fe/Mn nodules in the $4 \mathrm{Bt} / 4 \mathrm{Bc}$ transition (PPL); $\mathbf{d} \mathrm{Fe} / \mathrm{Mn}$ hypocoating in the $4 \mathrm{Bt} / 4 \mathrm{Bc}$ transition (PPL)
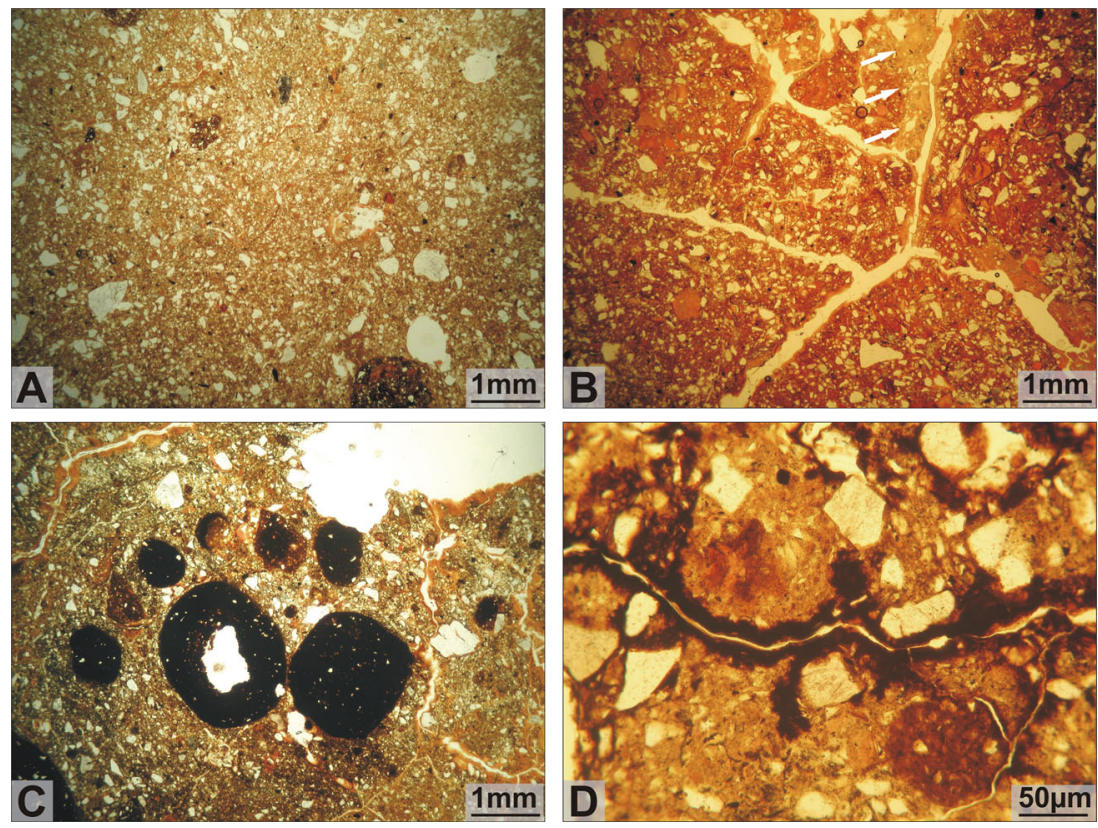


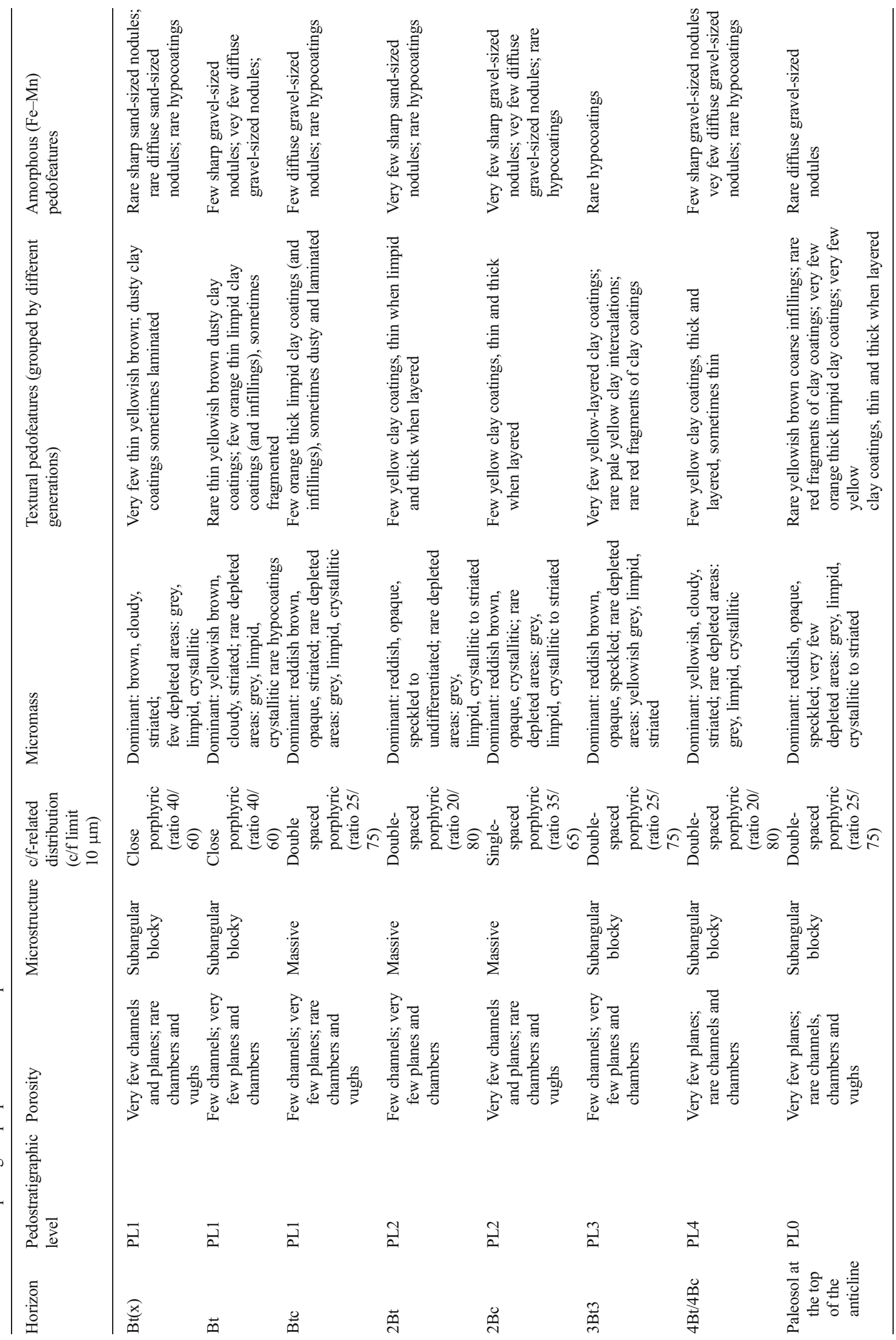


Fig. 7 Photomicrographs of thin sections illustrating pedofeatures related to clay redistribution. a Yellowish brown dusty clay coatings from the $\mathrm{Bt}(\mathrm{x})$ horizon (PPL); b limpid clay infilling in the Btc horizon (PPL); $\mathbf{c}$ yellow clay coatings in the $2 \mathrm{Bt}$ horizon (PPL); $\mathbf{d}$ pale yellow clay intercalations in the $3 \mathrm{Bt} 3$ horizon (PPL); e a fragment of red clay coating (papula) in the $3 \mathrm{Bt} 3$ horizon (PPL); f yellow-layered clay coatings from the $4 \mathrm{Bt} / 4 \mathrm{Bc}$ transition (PPL)

Fig. 8 Heavy mineral weathering indexes (Brewer 1964; Cremaschi 1978) of the pedosedimentary sequence of Monte Netto
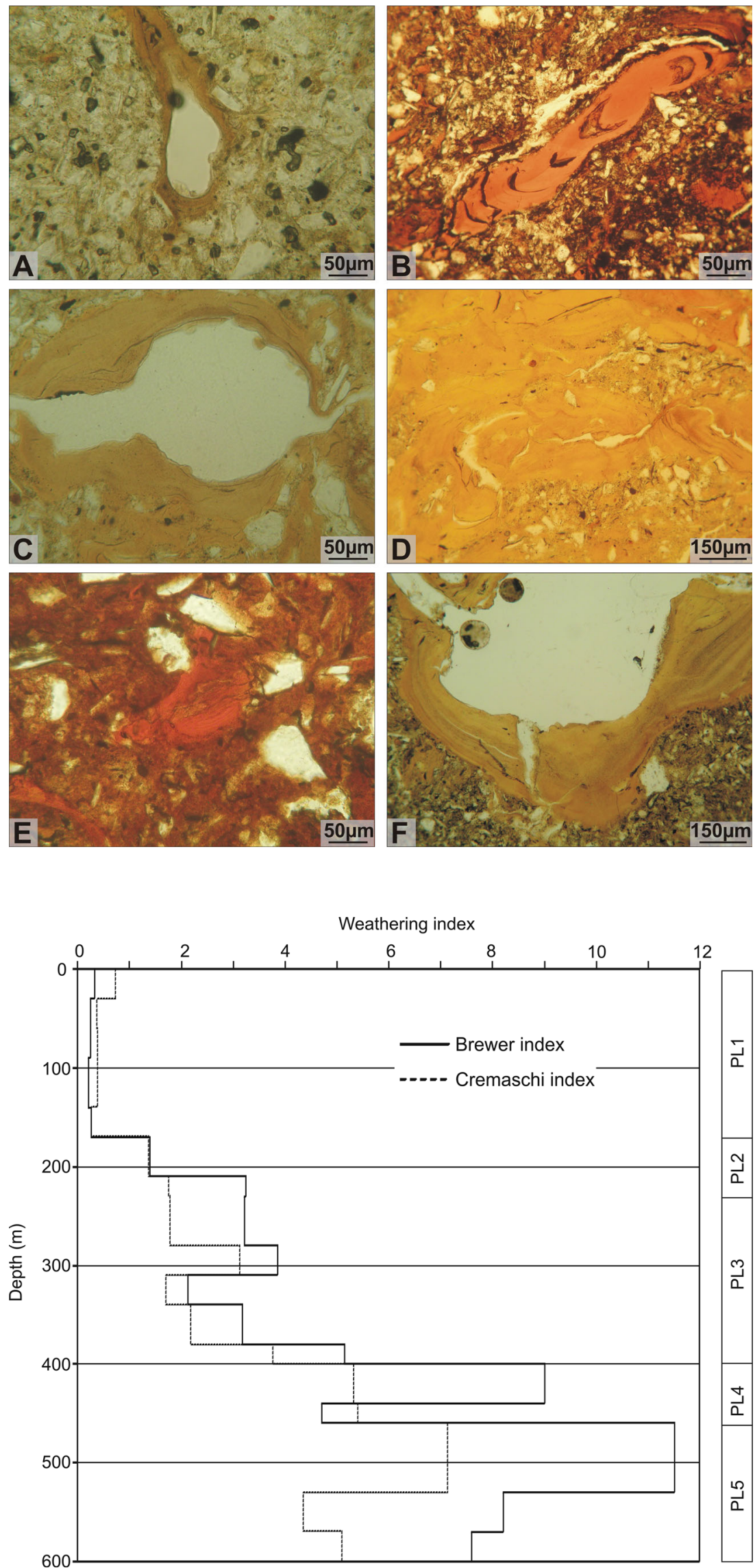
Fig. 9 Selected cumulative grain size curves for the

pedostratigraphic levels at Monte Netto compared to variability of grain size distribution in loess deposits in the PPLB according to Cremaschi (1987, 2004). The shadow indicates the field of variability of particle size distribution, the black solid curve indicates the fresh loess, the dashed black curve shows weathered loess. PL3' and PL5' indicate the less weathered parts of the levels

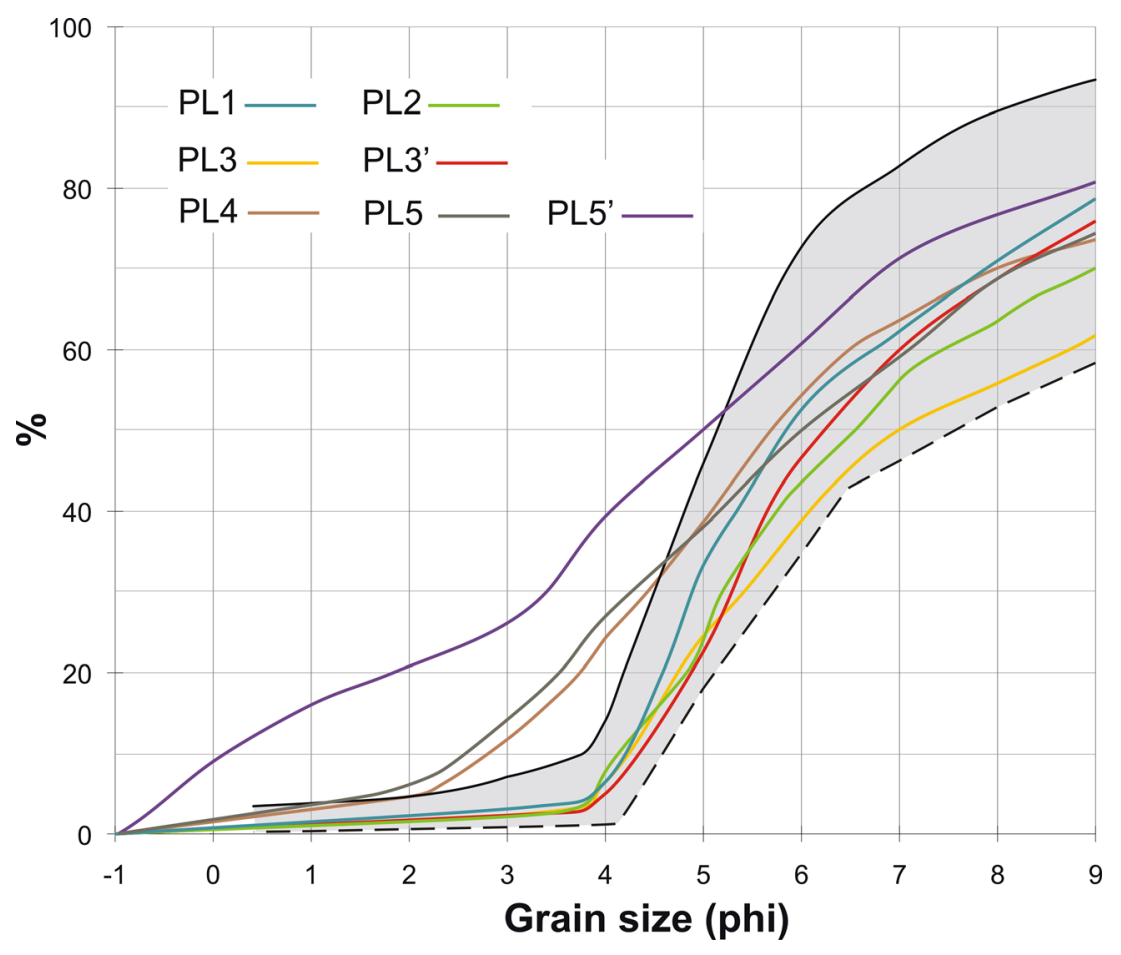

attested by yellow, layered clay coatings, which could indicate the increasing depth of Bt horizons (Chartres 1987) and that the illuviation process was either active over several events and/or had variable intensity (Kühn 2003; Kühn et al. 2010). Other textural pedofeatures, namely clay intercalations, are related to groundwater movements (hydromorphic phenomena) affecting the horizon, as discussed by Fedoroff et al. (2010). On the other hand, the weathering rate is clearly less intense in the $3 \mathrm{CBt}$ and $3 \mathrm{Cc}$ horizons, which show grain size distribution cumulative curves comparable to those of PL1, namely moderately weathered loess of the PPLB.

- The pedostratigraphic level PL4 has a different sedimentary history. Its grain size cumulative curves suggest a colluvial deposit. Moreover, the heavy mineral assemblage of this level is indicative of a change in the source of the parent material, mineralogically similar to the underlying PL5. However, from a pedological point of view, PL4 still shows a higher degree of weathering for the $4 \mathrm{Bt}$ horizon compared to the $4 \mathrm{Bc}$, mainly due to the field characteristics and the heavy mineral weathering indexes. With regard to micromorphology, the thin sections sampled at the boundary between the two described horizons show the same yellow-layered clay coatings as described in PL3 and the amorphous pedofeatures testifying the development of hydromorphic processes with depth.

- The pedostratigraphic level PL5 is developed on a parent material deriving from fluvial to fluvioglacial sediments, and it is, from a mineralogical point of view, rather similar to the parent material of the overlying PL4 level. Also in this case, the top horizons are more weathered than the deeper ones, reaching the highest weathering in the $5 \mathrm{Bt}$ horizon as attested by the heavy mineral weathering indexes.

According to their pedogenetic characteristics and the degree of development of the B horizons constituting the PLs of the Monte Netto pedosedimentary sequence, the soils can be tentatively classified as Luvisols (WRB 2006) or Alfisols (Soil Survey Staff 2010), where diagnostic properties are related to clay differentiation (migration) between the topsoil and the subsoil. Further levels of classification are merely speculative: in fact, with respect to reddening, some of the soils can be defined as Chromic Luvisols (WRB 2006) and Xeralfs (Soil Survey Staff 2010). On the other hand, the hydromorphic features also suggest Gleyic Luvisols (WRB 2006) and Aqualfs (Soil Survey Staff 2010). Finally, being buried paleosols, for their classification, the prefixes Thapto(WRB 2006) and Pale- (Soil Survey Staff 2010) should be used.

Our results regarding the soil-forming processes that shaped the B horizons at Monte Netto can be compared with those obtained by Terhorst and Ottner (2003) and Khün et al. (2006) who studied the polycyclic Luvisols developed in loess at the top of the fluvial terraces of Oleggio and Mezzomerico (northwestern Italy). In fact, at these localities in old loess sediments, possibly dating to the Lower and/or Middle Pleistocene (Bini and Zuccoli 2004), a very articulated sequence of $\mathrm{Bt}$ horizons was formed, representing different stages of soil formation. On the basis of palaeopedological 
indicators, micromorphology and clay mineralogy, Terhorst and Ottner (2003) and Khün et al. (2006) suggested that several pedogenetic phases occurred under interglacial climatic conditions that promoted the neoformation of clays and their strong illuviation along the soil profiles, which actually consist of a series of superimposed Bt horizons. The affinity between the main pedogenetic processes described above and those identified at Monte Netto is evident; even though in our case study loess deposits are considerably younger, the regularity of soil formation on similar parent material and in similar relief position (according to the concepts dealing with the genesis of soils introduced by Dokuchaev (1883) and formalized by Jenny (1941); see also Sprafke et al. (2013)) is confirmed. Soil formation mainly comprised clay illuviation and the formation of a sequence of Bt horizons. The main difference between the pedogenetic processes described from the Oleggio and Mezzomerico terraces and those identified at Monte Netto consists in the occurrence in our case study of a surficial water table, whose fluctuation promoted the formation of hydromorphic features after the illuviation of clay in the Bt horizons.

5.2 Evolution of the sequence: sedimentation, weathering, tectonic deformation and human frequentation

OSL dating was performed on the quartz grains, present in the $4-11-\mu \mathrm{m}$ fraction of poorly to moderately weathered silty sediments and indicates that the loess deposition (sedimentation of parent material of PL1 and PL2) was active for at least 25 ka during Marine Isotopic Stages 3 and 2 (MIS 3 and MIS 2). Unfortunately, samples collected for the lowermost loess body (PL3), which are moderately to intensely weathered, gave inconclusive results. In any case, the existence of level PL3, which also developed in a loess deposit, suggests that the environmental conditions suitable for loess accretion started well before $45 \mathrm{ka}$ and possibly date back to the beginning of MIS 4. This hypothesis is supported by the comparison with other radiometrically dated loess deposits along the PPLB (see below).

The interpretation of radiocarbon results requires more attention. In fact, sample CAP03 was collected from a weakly developed soil on loess, but its depth rules out contamination by younger organic matter. CAP03 possibly represents the age of a soil developed under glacial conditions in a tundra steppe environment with accumulation of organics and microcharcoals and later isolated from the surface. It is comparable to the cumulic soil (Soil Survey Staff 1999) described at the top of the Val Sorda loess sequence (Cremaschi et al. 1987; Ferraro 2009), not far from Monte Netto; at this site, radiocarbon dating of the cumulic soil was regarded as reliable representing a mean value for the time of soil development (Cremaschi et al. 1987). We therefore tend to refer the lowermost ${ }^{14} \mathrm{C}$ age of $16.2-15.8 \mathrm{cal} \mathrm{ka} \mathrm{BP}$ to a period of reduced wind strength (Ferraro 2009), marked by a low rate of loess sedimentation and continuous accumulation of organic matter. In any case, CAP03 radiocarbon result confirms aeolian sedimentation and loess accretion at Monte Netto also after the end of the LGM, probably during the stadial preceding the Bølling-Allerød interstadial (Orombelli and Ravazzi 1996). Meanwhile, samples CAP01 and CAP02 yielded Holocene ages for the upper part of the sequence (7.5-7.3 and 5.6$5.1 \mathrm{cal} \mathrm{ka} \mathrm{BP}$ ). Holocene aeolian deposits (mainly dust) have been occasionally reported form central and southern Italy (e.g. Frezzotti and Giraudi 1990; Costantini et al. 2009), but if we take into account the northern Italy, loess accretion can be considered as a process limited to the Pleistocene (Cremaschi 1987, 1990a, b, 2004; Cremaschi et al. 2014; Amit and Zerboni 2013). Moreover, a number of palaeohydrological records from northern Italy suggest that in the Early and Middle Holocene, this area was dominated by humid environmental conditions (e.g. Baroni et al. 2006; Zanchetta et al. 2007; Zhornyak et al. 2011), and pollen spectra indicate the persistence of a continuous vegetal cover in the Po Plain (e.g. Wick 1996; Amorosi et al. 2004; Pini 2004; Valsecchi et al. 2006; Kaltenrieder et al. 2010; Ravazzi et al. 2012, 2013). Further, few arid spells have been identified in local paleoclimatic records (e.g. Sadori and Narcisi 2001; Allen et al. 2002; Cremaschi et al. 2006; Giraudi et al. 2011; Peyron et al. 2011; Mercuri et al. 2011, 2012; Dinelli et al. 2012; Joannin et al. 2014); their intensity triggered limited changes to the vegetation cover of the Po Plain (Mercuri et al. 2011, 2012), which in the Holocene did not reach the environmental conditions of arid steppe allowing (as happened in the Upper Pleistocene) the transportation and sedimentation of silt by wind. Therefore, in the case of samples CAP01 and CAP02, the attribution of radiocarbon dating results to loess formation is not possible: samples were collected in a part of the topsoil close to the limit of present-day ploughing, and dating results may indicate an Early to Mid-Holocene pedogenesis under a warm climate allowing for the accumulation of organic matter, rather than a phase of aeolian sedimentation. Moreover, if we took into consideration a well-known loess site at the southern margin of the PPLB (the Ghiardo site: Cremaschi and Christopher 1984; Cremaschi 1987), we may advance a further hypothesis to explain the Holocene age of samples CAP01 and CAP02. In fact, at Ghiardo in the Holocene, thanks to the occurrence of a continuous vegetal cover, the upper strata of Pleistocene loess underwent a strong reworking, which allowed the accumulation of young organics in the topsoil (Cremaschi 1987; Cremaschi et al. 2014); possibly the same processes described for the Ghiardo site may have occurred also at the top of the Monte Netto hill, confirming that Holocene radiocarbon ages should be attributed to a pedogenesis under a warm climate.

If we integrate OSL and radiocarbon age results with archaeological finds and compare these data to other 
pedosequences in the area (Cremaschi 1987) and data concerning the Pleistocene evolution of the northern sector of the Po Plain, we can draw a picture of Upper Pleistocene environmental changes in the area. OSL results suggest that loess deposition (i.e. glacial conditions) was active c. $45 \mathrm{ka}$ $\mathrm{BP}$, but dust sedimentation started earlier already. This is confirmed by the occurrence of a thick in situ loess unit (PL3) underlying the dated levels. If we take into account other radiometric datings for loess available in the PPLB (e.g. Cremaschi 1987, 1990a, b, 2004; Cremaschi et al. 2011), we can postulate that loess sedimentation presumably started at the onset of glacial conditions, soon after the beginning of MIS 4. It is possible that the rate of dust sedimentation increased during MIS 4 and MIS 3. As observed elsewhere (Cremaschi et al. 2011), the persistence of glacial conditions permitted the increase of aridity in the area and the strengthening of the wind responsible for deflation and dust transportation. The lowermost radiocarbon dating, which falls beyond the end of the LGM, indicates a later phase of loess sedimentation at Monte Netto almost contemporaneous with dust sedimentation recorded in other loess sequences along the northern margin of the PPLB, such as at Val Sorda, in the valleys of Trentino, in the upper Apennines, and at Susak island, along the Dalmatian coast (Cremaschi and Lanzinger 1984; Cremaschi et al. 1987; Ferraro 2009; Wacha et al. 2011; Negrino et al. 2014).

During phases of reduced sedimentation, and possibly due to a decreased wind intensity during interstadials, the effects of pedogenesis may have been more intense, as confirmed by the occurrence of thin soils in the pedosedimentary sequence at Monte Netto. These periods were possibly longer during the initial phases of loess sedimentation, as the thickness and reddening of soils decrease from PL3 to PL1. On the contrary, the deeply rubified paleosol at the base of the sequence (PL4), formed in colluvium of fluvioglacial deposits, shows a strong degree of alteration, which is possible only under interglacial conditions. Also the argillic B horizon developed at the top of PL5 represents a truncated paleosol, whose formation requires warm and humid conditions. Moreover, the retrieval of a Lower/Middle Palaeolithic lithic assemblage from the soil at the top of PL4 offers a post quem limit for its formation. The chronological definition of this pedogenetic phase in a tectonically active site is difficult, also considering that each interglacial may have produced similar results in terms of weathering (Sprafke et al. 2013). We tentatively propose an attribution of these paleosols to the penultimate and/or last interglacials. In this sense, the soil at the top of PL4 would represent an analogue to other Eemian paleosols found in northern Italy (e.g. Cremaschi 1987; Ferraro 2009). To summarize, the lowermost soils developed on fluvial/fluvioglacial and colluvial sediments (PL5 and PL4) and likely formed during MIS 7 and MIS 5 interglacials. Dust accumulation commenced when climate reached glacial conditions and the
Po Plain was an arid steppe during the MIS 4. Finally, a long polycyclic cold phase, interrupted by brief interstadials, permitted the formation of the remaining part of the succession (PL3, PL2, PL1).

A complete understanding of the evolution of the pedosequence requires also to take into account the seismotectonic history of the study area. As discussed by Livio et al. $(2009,2012)$, the origin of the anticline at the core of the section was triggered by a buried backthrust. The shallower expression of this blind fault is a complex array of fault-related folds, which deformed the overlying fluvial to fluvioglacial sediments. This process, possibly occurring during the Middle Pleistocene, led to the uplift of the parent material of PL5, its weathering under warm interglacial conditions (MIS 7?) and its subsequent truncation (MIS 6?). The continuous growth of the structural crest of the anticline led to the asymmetric development of the sequence; the emergence of a morphological relief allowed the onset of erosional processes and the deposition of a thick colluvial unit (PL4) at the base of the anticline (MIS 6?). PL4 also underwent strong pedogenesis under interglacial conditions (MIS 5?) and was then buried by loess deposited under glacial conditions (possibly MIS 4 and definitely during MIS 3 and MIS 2). Dust sedimentation was promoted by long-lasting cold-arid conditions, but the formation of the exceptional thick deposit (compared to other occurrences at the margins of the Po Plain, generally limited to a few tens of centimetres up to $1 \mathrm{~m}$; for more details, see Cremaschi, 1987, 1990a) was favoured by the presence of a topographic obstacle (sensu Pye 1995) represented by the Monte Netto hill. In the Po Plain, the thickest loess deposits are always related to topographic obstacles, such as terraces along the margin of the Alps and isolated hills in northern Lombardia (Desio 1965; Baroni and Cremaschi 1986; Cremaschi 1987; Baroni et al. 1988; Terhorst and Ottner 2003; Ferraro 2009; Cremaschi et al. 2014). Moreover, at Monte Netto, the continuous growth of the anticline that displaced geological strata at the top of the hill (Livio et al. 2009) strengthened the role played by the hill as a local sediment trap for aeolian silt, allowing the existence of an obstacle for most of the Upper Pleistocene. Finally, we notice that the thickest loess body on the top of the Monte Netto hill is facing the Po Plain. This is in agreement with Cremaschi (1987, 1990a), who reported that the prevailing wind direction was from the central part of the Po Plain towards the margins of Alps and Apennines (Fig. 1).

During loess sedimentation, the area around Monte Netto was characterized by a cold and arid climate and a steppe environment. Still, the presence of a rich assemblage of lithics within the upper loess cover (PL2) suggests that the environmental conditions were suitable for the survival of groups of Mousterian hunters, wandering along the Alpine foreland looking for game. The occurrence of these artefacts is not the only evidence of human presence in the PPLB under 
glacial climate conditions. In fact, many other loess sites surrounding the Po Plain yielded similar finds, including the Fumane and Tagliente caves (Cremaschi 1990b; Cremaschi 2000; Peresani et al. 2008), the Bagaggera (Cremaschi et al. 1990) and Ghiardo sequences (Cremaschi and Christopher 1984; Cremaschi 1987; Cremaschi et al. 2011) and the karst depressions on the Berici plateau (Peresani and Nicosia, in press). Furthermore, the proximity of the Monte Netto region to the Pre-Alps, where Mousterian people settled in rock shelters, implies the presence of nomadic hunting groups, moving between the Po Plain and the neighbouring Alpine fringe.

\section{Conclusions}

The pedostratigraphic investigation of the Monte Netto pedosedimentary sequence allows us to reconstruct the environmental changes in the central Po Plain since the Middle Pleistocene. It represents a landscape shaped by the interaction of seismotectonic (uplift and deformation) and surface-related (aeolian sedimentation and pedogenesis) processes. This area offers a good opportunity to study the effects of soil-forming processes under different environmental conditions, resulting in different stages of pedogenesis, which can be linked to the overall progressive cooling during the last glacial cycle (Schulz 2002; Fleitmann et al. 2009).

Furthermore, the different degree of loess weathering also represents one of the key peculiarities of the loess from the PPLB (Amit and Zerboni 2013). In fact, due to the geographical position of northern Italy, the PPLB loess was highly sensitive to climate changes and the interlayered paleosols recorded short-lived climate changes, as shown at Monte Netto.

Loess sedimentation at Monte Netto occurred at least during MIS 3 and 2, and it is possible that some loess also formed after the LGM. A deeper loess unit (PL3) was not dated, but it is inferred that it formed during MIS 4. At the northern fringe of the PPLB, loess formation was dated at Val Sorda, Gajum, Bagaggera and within rock shelters to the period between MIS 4 and 2 (Cremaschi 1987; Cremaschi et al. 1987; Castiglioni et al. 1990; Cremaschi 1990a; Accorsi et al. 1990; Peresani et al. 2008; Ferraro 2009; Scardia et al. 2010), while postLGM loess accretion occurred only in the valleys of Trentino (Cremaschi and Lanzinger 1984, 1987; Dalmeri 1992; Borsato 2009). Dust deposition in the PPLB hence occurred under glacial conditions after the end of a warm MIS 5, confirmed by other terrestrial records (Pini et al. 2009, 2010). Moreover, the phase of loess accretion corresponds to a huge expansion of the Po Plain after the lowering of the Adriatic sea level (to a low-stand of at least $-100 \mathrm{~m}$ at the end of the LGM), enhanced aggradation of fine-grained fluvioglacial sediments and an increase in aridity (e.g. Cremaschi 1987, 2004; Waelbroeck et al. 2002; Lambeck and Purcell 2005; Monegato et al. 2011).

Finally, Mousterian occupation at Monte Netto was contemporaneous with loess accretion and therefore occurred when the Po Plain was an arid and cold steppe. This is further confirmation that during the Upper Pleistocene, groups of hunters migrated between the pre-Alps and the Po Plain despite harsh environmental conditions.

Acknowledgments We would like to thank the municipality of Capriano del Colle (BS) and the Major for their warm hospitality during field work. The owners of Cave Danesi are also acknowledged for allowing us to work in the quarry. The Soprintendenza per i Beni Archeologici della Lombardia is thanked for its support. Mauro Cremaschi is thanked for his continuous support during the investigation at Monte Netto and the preparation of the manuscript. Sergio Ando is acknowledged for assistance in heavy mineral preparation, identification and interpretation. This work has been in part funded by grants from the Operational Programme Cross Border Cooperation IT/CH 2007-2013project 'SITINET: census, networking and development of geological and archaeological sites' ID 7621984. Additional funding for field activities and laboratory analyses was provided by the Università degli Studi di Milano. This manuscript benefitted from fruitful discussions with many researchers during the 'Soil formation and weathering in time and space' session at the EGU General Assembly 2013 and the INQUA-AEOMED meeting 'Reconsidering loess in northern Italy' (July 2013); a special thanks is extended to R. Amit. E. Modrall is kindly acknowledged for the skilful revision of English language. Comments from two anonymous reviewers and the guest editor F. Scarciglia helped in improving the quality of the final version of the manuscript.

\section{References}

Accorsi CA, Baroni C, Carton A, Cremaschi M, Filippi N, Magnani P, Maggi W, Nisbet R (1990) The loess at the Apennine fringe. In: Cremaschi M (ed) The loess in Northern and Central Italy: a loess basin between the Alps and the Mediterranean Sea. C.N.R., Centro di Studio per la Stratigrafia e Petrografia delle Alpi Centrale, Milano, Italy, pp. 73-101

Adamiec G, Aitken MJ (1998) Dose-rate conversion factors: update. Ancient TL 16:37-49

Amit R, Zerboni A (2013) Report on the INQUA-AEOMED field-trip workshop 'Reconsidering Loess in Northern Italy' (Po Plain, 1-3 July 2013). AMQ - Alpine and Mediterranean Quaternary 26(2):xi$\mathrm{xV}$

Allen JRM, Watts WA, McGee E, Huntley B (2002) Holocene environmental variability - the record from Lago Grande di Monticchio, Italy. Quatern Int 88:69-80

Amorosi A, Colalongo ML, Fiorini F, Fusco F, Pasini G, Vaiani SC, Sarti G (2004) Palaeogeographic and palaeoclimatic evolution of the Po Plain from 150-ky core records. Global Planet Chang 40:55-78

Assallay AM, Jefferson IF, Rogers CDF, Smalley IJ (1998) Fragipan formation in loess soils: development of the Bryant hydroconsolidation hypothesis. Geoderma 83:1-16

Banerjee D, Murray AS, Bøtter-Jensen L, Lang A (2001) Equivalent dose estimation using a single aliquot of polymineral fine grains. Radiat Meas 33:73-94

Baroni C, Cremaschi M (1986) Geologia e pedostratigrafia della Collina di Ciliverghe (Brescia). Natura Bresciana 23:55-78 
Baroni C, Cremaschi M, Fedoroff N (1988) The stratigraphy of the Castenedolo hill. In: Cremaschi M (ed) The loess in Northern and Central Italy: a loess basin between the Alps and the Mediterranean Sea. C.N.R., Centro di Studio per la Stratigrafia e Petrografia delle Alpi Centrale, Milano, Italy, pp 61-72

Baroni C, Zanchetta G, Fallick AE, Longinelli A (2006) Mollusca stable isotope record of a core from Lake Frassino, northern Italy: hydrological and climatic changes during the last $14 \mathrm{ka}$. The Holocene 16: $827-837$

Bini A, Zuccoli L (2004) Glacial history of the southern side of the central Alps, Italy. In: Ehlers J, Gibbard PL (eds) Quaternary glaciationsextent and chronology. Elsevier, Amsterdam, pp 195-200

Borsato A (2009) Depositi loessici in Trentino: caratteristiche morfologiche, tessiturali, mineralogiche e pedologiche. Studi Trentini Scienze Naturali 85:51-59

Bos RHG, Sevink J (1975) Introduction of gradational and pedomorphic features in descriptions of soils. J Soil Sci 26:223-233

Brewer R (1964) Fabric and mineral analysis of soils. John Wiley and Sons, New York

Bronger A, Sedov S (2003) Vetusols and paleosols: natural versus maninduced environmental change in the Atlantic coastal region of Morocco. Quatern Int 106-107:33-60

Bullock P, Fedoroff N, Jongerius A, Stoops G, Tursina T, Babel U (1985) Handbook for soil thin section description. Waine Research Publication, Albrighton, ST, USA

Busacca A, Cremaschi M (1998) The role of time versus climate in the formation of deep soils of the Apennine fringe of the Po Valley, Italy. Quatern Int 51-52:95-108

Capeder G (1898) Osservazioni geologiche e petrografiche sull'anfiteatro morenico di Rivoli. Tipo-Litografia Toffaloni, Torino, Italy

Carcano C, Piccin A (2002) Geologia degli acquifi Padani della Regione Lombardia. S.EL.CA, Firenze

Castellarin A, Vai G (1986) Southalpine versus Po Plain Apeninic Arcs. In: Wezel FC (ed) The origin of arcs. Elsevier Science Publisher B. $\mathrm{V}$, Amsterdam, pp 253-280

Castellarin A, Vai G, Cantelli L (2006) The Alpine evolution of the Southern Alps around the Giudicarie faults: a Late Cretaceous to Early Eocene transfer zone. Tectonophysics 414:203-223

Castiglioni GB, Cremaschi M, Guerreschi A, Meneghel M, Sauro U, Van Vliet LB (1990) The loess deposits in the Lessini plateau. In: Cremaschi $\mathrm{M}$ (ed) The loess in Northern and Central Italy: a loess basin between the Alps and the Mediterranean region. CNR, Milano, pp 41-59

Chartres CJ (1987) The composition and formation of grainy void coatings in some soils with textural contrast in Southeastern Australia. Geoderma 39:209-233

Costantini EAC, Priori S (2007) Pedogenesis of plinthite during early Pliocene in the Mediterranean environment. Case study of a buried paleosol at Podere Renieri, central Italy. Catena 71:425-443

Costantini EAC, Priori S, Urban B, Hilgers A, Sauer D, Protano G, Trombino L, Hülle D, Nannoni F (2009) Multidisciplinary characterization of the middle Holocene eolian deposits of the Elsa River basin (central Italy). Quaternary International 209(1-2): 107-130

Coudé-Gaussen G (1990) The loess and loess-like deposits along the sides of the western Mediterranean Sea: genetic and palaeoclimatic significance. Quatern Int 5:1-8

Cremaschi M (1974) Manufatti del Paleolitico medio-inferiore, provenienti da Monte Netto di Brescia e loro rapporti con i depositi quaternari del Colle. Natura Bresciana 11:41-57

Cremaschi M (1978) Unità Litostratigrafiche e Pedostratigrafiche nei Terreni Quaternari Pedeappenninici; Loess e Paleosuoli tra il Fiume Taro e il Torrente Sillaro. Geografia Fisica e Dinamica del Quaternario 1:4-22

Cremaschi M (1987) Paleosols and vetusols in the Central Po Plain Northern Italy: a study in Quaternary geology and soil development. Unicopoli, Milano
Cremaschi M (1990a) The loess in Northern and Central Italy: a loess basin between the Alps and the Mediterranean Sea. C.N.R., Centro di Studio per la Stratigrafia e Petrografia delle Alpi Centrale, Milano, Italy

Cremaschi M (1990b) Depositional and post-depositional processes in rock shelters of northern Italy during the late Pleistocene: their paleoclimatic and paleoenvironmental significance. Quaternaire 1: $51-64$

Cremaschi M (2000) Manuale di Geoarcheologia. Laterza Editore, Bari, Italy

Cremaschi M (2004) Late Pleistocene loess. In: Antonioli F, Vai GB (eds) Litho-palaeoenvironmental maps of Italy during the last two climatic extremes. Climex Maps Italy - Explanatory notes, Bologna, pp 34-37

Cremaschi M, Alessio M, Allegri L, Azzi C, Calderoni G, Cortesi C, Petrone V, Spezzi Bottiani G (1987) Una data radiocarbonica del palaeosuolo su loess incluso nella successione stratigrafica della Val Sorda (sistema morenico del Garda). Rend Soc Geol Ital 10:29-32

Cremaschi M, Christopher C (1984) Palaeolithic settlement and environment in the Middle Pleistocene of Northern Italy: the Ghiardo site. The Third Conference of Italian Archaeology, vol I, The Environment. B.A.R., London, pp 87-104

Cremaschi M, Fedoroff N, Guerreschi A, Huxtable J, Colombi N, Castelletti L, Maspero A (1990) Sedimentary and pedological processes in the upper Pleistocene loess of Northern Italy. The Bagaggera sequence. Quatern Int 5:23-38

Cremaschi M, Pizzi C, Valsecchi V (2006) Water management and land use in the terramare and a possible climatic co-factor in their abandonment: the case study of the terramara of Poviglio Santa Rosa (northern Italy). Quatern Int 151:87-98

Cremaschi M, Rodnight H, Zerboni A, Spötl C (2011) Loess in Northern Italy. New insights on dating, environment and archaeology. Il Quaternario 24:95-97

Cremaschi M, Negrino F, Magnani P, Zerboni A, Nicosia C, Rodnight H, Spötl C (in press) Il sito Paleolitico di Ghiardo Cave: industrie, cronologia, ambiente. Atti della XLV Riunione Scientifica IIPP 'Preistoria e Protostoria dell'Emilia-Romagna'

Cremaschi M, Lanzinger M (1984) La successione stratigrafica e le fasi pedogenetiche del sito epigravettiano di Andalo, i loess tardiglaciali della Val d'Adige. Preistoria Alpina 19:179-188

Cremaschi M, Lanzinger M (1987) Studio pedostratigrafico e geomorfologico dell'area circostante il sito tardo paleoliticomesolitico di Terlago (Trento). Studi Trentini Scienze Naturali. Acta Geol 64:99-120

Cremaschi M, Zerboni A, Nicosia C, Negrino F, Rodnight H, Spötl C (2014) Age, soil-forming processes, and archaeology of the loess deposits at the Apennine margin of the Po Plain (northern Italy). New insights from the Ghiardo area (in press)

Dalmeri G (1992) Ricerche nel sito Tardopaleolitico-Mesolitico di Terlago (Trentino). Tracce di strutture di abitato. Natura Bresciana 28:433-461

Desio A (1965) I rilievi isolati della Pianura Lombarda ed i movimenti tettonici del Quaternario. Rend Ist Lom Acc Sc Lett, Sez A 99:881894

Dinelli E, Ghosh A, Rossi V, Vaiani SC (2012) Multiproxy reconstruction of Late Pleistocene-Holocene environmental changes in coastal successions: microfossil and geochemical evidences from the Po Plain (Northern Italy). Stratigraphy 9:153-167

Duchaufour P (1983) Pédologie 1: Pédogenèse et Classification. Masson, Paris

Dokuchaev VV (1883) Russian Chernozem. Independent Society for Economics, St. Petersburg

Durn G, Aljinović D, Crnjaković M, Lugović B (2007) Heavy and light mineral fractions indicate polygenesis of extensive terra rossa soils in Istria, Croatia. In: Mange MA, Wright DT (eds) Heavy minerals 
in use, vol 58, Developments in Sedimentology Series. Elsevier, Amsterdam, pp 701-737

Erhart H (1951) La genèse des sols en tant que phénomène géologique. Esquisse d'une théorie géologique et géochimique. Biostasie et rhéxistasie, Masson, Paris

ERSAL (2001) Carta dei pedopaesaggi della Lombardia - 1:250’000. S.EL.CA, Firenze

Fantoni R, Bersezio R, Forcella F (2004) Alpine structure and deformation chronology at the Southern Alps-Po Plain border in Lombardy. Boll Soc Geol Ital 123:463-476

FAO (1998) World reference base for soil resources. World Soil Resources Report 84, ISSS-ISRIC-FAO, Rome, Italy

FAO (2006) Guidelines for soil description, 4th edn. Food and Agriculture Organization of the United Nations, Rome, Italy

FAO-UNESCO (1971) Soil map of the world 1:5,000,000. UNESCO, Paris, France

Fedoroff N, Goldberg P (1982) Comparative micromorphology of two Late Pleistocene paleosols (in the Paris Basin). Catena 9: $227-251$

Fedoroff N, Courty M, Guo Z (2010) Palaeosoils and relict soils. In: Stoops G, Marcelino V, Mees F (eds) Interpretation of micromorphological features of soils and regoliths. Elsevier, Oxford

Ferraro F (2009) Age, sedimentation, and soil formation in the Val Sorda loess sequence, Northern Italy. Quatern Int 204:54-64

Fleitmann D, Cheng H, Badertscher S, Edwards R.L., Mudelsee M, Göktürk O.M., Fankhauser A, Pickering R, Raible CC, Matter A, Kramers J, Tüysüz O (2009) Timing and climatic impact of Greenland interstadials recorded in stalagmites from northern Turkey. Geophysical Research Letters, 36: L19707, doi:10.1029/ 2009GL040050

Forno MG (1979) Il loess della collina di Torino: revisione della sua distribuzione e della sua interpretazione genetica e cronologica. Geografia Fisica e Dinamica Quaternaria 2:105-124

Frezzotti M, Giraudi C (1990) Late Glacial and Holocene aeolian deposits and features near Roccaraso (Abruzzo, Central Italy). Quat Int 5:89 95

Galbraith R, Roberts R, Laslett G, Yoshida H, Olley J (1999) Optical dating of single and multiple grains of quartz from Jinmium rock shelter, northern Australia: part I, experimental design and statistical models. Archaeometry 41:339-364

Gale SJ, Hoare PG (1991) Quaternary sediments. Belhaven Press, London

Garzanti E, Andò S (2007a) Heavy mineral concentration in modern sands: implication for provenance interpretation. In: Mange MA, Wright DT (eds) Heavy minerals in use. Developments in Sedimentology Series, vol. 58, Elsevier, Amsterdam, pp 517-545

Garzanti E, Andò S (2007b) Plate tectonics and heavy mineral suites of modern sands. In: Mange MA, Wright DT (eds) Heavy minerals in use. Developments in Sedimentology Series, vol. 58, Elsevier, Amsterdam, pp 741-763

Giraudi C, Magny M, Zanchetta G, Drysdale RN (2011) The Holocene climatic evolution of Mediterranean Italy: a review of the continental geological data. The Holocene 21:105-115

Haase D, Fink J, Haase G, Ruske R, Pécsi M, Richter H, Altermann M, Jäger K-D (2007) Loess in Europe - its spatial distribution based on a European Loess Map, scale 1:2,500,000. Quatern Sci Rev 26: 1301-1312

James WC, Mack GH, Monger HC (1998) Paleosol classification. Quatern Int 51-52:8-9

Jenny H (1941) Factors of soil formation. A system of quantitative pedology. McGraw Hill Book Company, New York

Joannin S, Magny M, Peyron O, Vannière B, Galop D (2014) Climate and land-use change during the late Holocene at Lake Ledro (southern Alps, Italy). The Holocene 24:591-602
Jongerius A (1983) The role of the micromorphology in agricultural research. In: Bullock P, Murphy CP (eds) Soil micromorphology, vol 1. AB Academic Press, Berkhamsted, pp 111-138

Kaltenrieder P, Procacci G, Vannière B, Tinner W (2010) Vegetation and fire history of the Euganean Hills (Colli Euganei) as recorded by Lateglacial and Holocene sedimentary series from Lago della Costa (northeastern Italy). The Holocene 20:679-695

Krasilnikov P, Calderón NFG (2006) A WRB-based buried paleosol classification. Quatern Int 156-157:176-188

Kühn P (2003) Spätglaziale und holozäne Lessivégenese auf jungweichselzeitlichen Sedimenten Deutschlands. Greifswalder Geographische Arbeiten 28, Greifswald, pp 167

Kühn P, Aguilar J, Miedema R (2010) Textural pedofeatures and related horizons. In: Stoops G, Marcelino V, Mees F (eds) Interpretation of micromorphological features of soils and regoliths. Elsevier, Oxford, pp 217-250

Khün P, Terhorst B, Ottner F (2006) Micromorphology of middle Pleistocene palaeosols in northern Italy. Quatern Int 156-157:156 166

Kulig G (2005) Erstellung einer Auswertesoftware zur Altersbestimmung mittels Lumineszenzverfahren unter spezieller Berücksichtigung des Einflusses radioaktiver Ungleichgewichte in der 238-UZerfallsreihe. Bakkalaureusarbeit Network Computing, TU Freiberg

Lambeck K, Purcell A (2005) Sea-level change in the Mediterranean Sea since the LGM: model predictions for tectonically stable areas. Quatern Sci Rev 24:1969-1988

Livio FA, Berlusconi A, Michetti AM, Sileo G, Zerboni A, Trombino L, Cremaschi M, Mueller K, Vittori E, Carcano C, Rogledi S (2009) Active fault-related folding in the epicentral area of the December 25, 1222 (Io=IX MCS) Brescia earthquake (Northern Italy): seismotectonic implications. Tectonophysics 476:320-335

Livio F, Berlusconi A, Zerboni A, Trombino L, Sileo G, Michetti AM, Spötl C, Rodnight H (2012) Active fold growth constrained by a loess-paleosol sequence (Monte Netto, Southern Alps). Rend Online Soc Geol Ital 22:126-129

Mange MA, Maurer HFW (1992) Heavy minerals in color. Chapman \& Hall, London

Marchetti M (1996) Variazioni idrodinamiche dei corsi d'acqua della Pianura Padana centrale connesse con la deglaciazione. Il Quaternario 9:465-472

Mauz B, Packman S, Lang A (2006) The alpha effectiveness in silt-sized quartz: new data obtained by single and multiple aliquot protocols. Ancient TL 24:47-52

Mercuri AM, Sadori L, Ollero PU (2011) Mediterranean and northAfrican cultural adaptations to mid-Holocene environmental and climatic changes. The Holocene 21:189-206

Mercuri AM, Bandini Mazzanti M, Torri P, Vigliotti L, Bosi G, Florenzano A, Olmi L, Massamba N'siala I (2012) A marine/ terrestrial integration for mid-late Holocene vegetation history and the development of the cultural landscape in the Po valley as a result of human impact and climate change. Veg Hist Archaeobot 21:353372

Monegato G, Pini R, Ravazzi C, Reimer PJ, Wick L (2011) Correlating Alpine glaciation with Adriatic sea-level changes through lake and alluvial stratigraphy. J Quat Sci 26:791-804

Mroczek P (2013) Recycled loesses - a micromorphological approach to the determination of local source areas of Weichselian loess. Quatern Int 296:241-250

Munsell $^{\circledR}$ (1994) Soil color charts, 1994 rev. ed. Munsell ${ }^{\circledR}$ Color, New Windsor

Murphy CP (1986) Thin section preparation of soils and sediments. AB Academic Publishers, Berkhamsted

Muttoni G, Carcano C, Garzanti E, Ghielmi M, Piccin A, Pini R, Rogledi S, Sciunnach D (2003) Onset of major Pleistocene glaciations in the Alps. Geology 31:989-992 
Negrino F, Colombo M, Cremaschi M, Serradimigni M, Tozzi C, Ghiretti C (2014) Estese officine litiche del Paleolitico medio-superiore sui rilievi appenninici di Monte Lama-Castellaccio-Pràrbera (Bardi, Parma). Atti della XLV Riunione Scientifica IIPP 'Preistoria e Protostoria dell'Emilia-Romagna' (in press)

Nettleton WD, Brasher BR, Benham EC, Ahrenst RJ (1998) A classification system for buried paleosols. Quatern Int 51:175-183

Nettleton WD, Olson CG, Wysocki DA (2000) Paleosol classification: problems and solutions. Catena 41:61-92

Orombelli G (1990) Loess in Italy: an introduction. In: Cremaschi M (Ed) The loess in Northern and Central Italy: a loess basin between the Alps and the Mediterranean Sea. C.N.R., Centro di Studio per la Stratigrafia e Petrografia delle Alpi Centrale, Milano, Italy, pp 11-12

Orombelli G, Ravazzi C (1996) The glacial and early Holocene chronology and paleoclimate. Il Quaternario 9:439-444

Parfenoff A, Pomerol C, Tourenq J (1970) Les minéraux en grains. Masson et C.ie Editeurs, Paris

Pecsi M, Richter G (1996) Löss. Herkunft e Gliederung e Landschafte. Z Geomorphol 98(Suppl):391

Peresani M, Nicosia C (in press) Comparative study of two Late Pleistocene sequences with paleosols and aeolian deposits at the Alpine foreland. Geografia Fisica e Dinamica Quaternaria

Peresani M, Cremaschi M, Ferraro F, Falgueres C, Bahain J-J, Gruppioni G, Sibilia E, Quarta G, Calcagnile L, Dolo J-M (2008) Age of the final Middle Palaeolithic and Uluzzian levels at Fumane Cave, Northern Italy, using 14C, ESR, 234U/230Th and thermoluminescence methods. J Archaeol Sci 35:2986-2996

Peyron O, Goring S, Dormoy I, Kotthoff U, Pross J, de Beaulieu J-L, Drescher-Schneider R, Vannière B, Magny M (2011) Holocene seasonality changes in the central Mediterranean region reconstructed from the pollen sequences of Lake Accesa (Italy) and Tenaghi Philippon (Greece). The Holocene 21:131-146

Pini R (2004) Late Neolithic vegetation history at the pile-dwelling site of Palù di Livenza (northeastern Italy). J Quat Sci 19:769-781

Pini R, Ravazzi C, Donegana M (2009) Pollen stratigraphy, vegetation and climate history of the last $215 \mathrm{ka}$ in the Azzano Decimo core (plain of Friuli, north-eastern Italy). Quat Sci Rev 28:1268-1290

Pini R, Ravazzi C, Reimer PJ (2010) The vegetation and climate history of the last glacial cycle in a new pollen record from Lake Fimon (southern Alpine foreland, N-Italy). Quat Sci Rev 29:3115-3137

Prescott JR, Hutton JT (1994) Cosmic ray contributions to dose rates for luminescence and ESR dating: large depths and long-term variations. Radiat Meas 23:497-500

Pye K (1987) Aeolian dust and dust deposits. Academic, London

Pye K (1995) The nature, origin and accumulation of loess. Quat Sci Rev 14:653-667

Ravazzi C, Deaddis M, De Amicis M, Marchetti M, Vezzoli G, Zanchi A (2012) The last $40 \mathrm{ka}$ evolution of the Central Po Plain between the Adda and Serio rivers. Géomorphologie : relief, processus, environnement, 2/2012:131-154

Ravazzi C, Marchetti M, Zanon M, Perego R, Quirino T, Deaddis M, De Amicis M, Margaritora D (2013) Lake evolution and landscape history in the lower Mincio Valley, unravelling drainage changes in the central Po Plain (N-Italy) since the Bronze Age. Quatern Int 288:195-205

Reimer PJ, Bard E, Bayliss A, Beck JW, Blackwell PG, Bronk Ramsey C, Buck CE, Edwards RL, Friedrich M, Grootes PM, Guilderson TP, Haflidason H, Hajdas I, Hatté C, Heaton TJ, Hoffman DL, Hogg AG, Hughen KA, Kaiser KF, Kromer B, Manning SW, Niu M, Reimer RW, Richards DA, Scott M, Southon JR, Staff RA, Turney CSM, van der Plicht J (2013) INTCAL13 and MARINE13 radiocarbon age calibration curves 0-50,000 years cal BP. Radiocarbon 55:1869-1887

Rellini I, Trombino L, Firpo M, Rossi PM (2009) Extending westward the loess basin between the Alps and the Mediterranean region: micromorphological and mineralogical evidences from the northern scope of the Ligurian Alps, Northern Italy. Geografia Fisica e Dinamica Quaternaria 32:103-116

Roberts HM, Wintle AG (2001) Equivalent dose determinations for polymineralic fine-grains using the SAR protocol: application to a Holocene sequence of the Chinese Loess Plateau. Quat Sci Rev 20: $859-863$

Sadori L, Narcisi B (2001) The postglacial record of environmental history from Lago di Pergusa, Sicily. The Holocene 11:655-670

Scardia G, Muttoni G, Sciunnach D (2006) Subsurface magnetostratigraphy of Pleistocene sediments from the Po Plain (Italy): constraints on rates of sedimentation and rock uplift. Geol Soc Am Bull 118(11/12):1299-1312

Scardia G, Donegana M, Muttoni G, Ravazzi C, Vezzoli G (2010) Late Matuyama climate forcing on sedimentation at the margin of the southern Alps (Italy). Quat Sci Rev 29:832-846

Schulz M (2002) The tempo of climate change during DansgaardOeschger interstadials and its potential to affect the manifestation of the 1470-year climate cycle. Geophys Res Lett 29:1002. doi:10. 1029/2001GL013277

Smalley IJ (1966) The properties of glacial loess and the formation of loess. J Sediment Petrol 36:669-676

Smalley I, Jary Z (2005) Where is the loess? (and why?). N Z Soil News 53:62-66

Smalley IJ, Jefferson IF, Dijkstra TA, Derbyshire E (2001) Some major events in the development of the scientific study of loess. Earth-Sci Rev 54:5-18

Soil Survey Staff (1999) Soil taxonomy — a basic system of soil classification for making and interpreting soil surveys. Natural Resources Conservation Service, US Department of Agriculture, Washington, DC, USA

Soil Survey Staff (2010) Keys to soil taxonomy. Natural Resources Conservation Service, US Department of Agriculture, Washington, DC, USA, 11th edition

Sprafke T, Thiel C, Terhorst B (2013) From micromorphology to palaeoenvironment: the MIS 10 to MIS 5 record in Paudorf (Lower Austria). Catena 117:60-72

Stoops G (1999) Guidelines for soil thin sections descriptions. International Training Centre for Post-Graduate Soil Scientists, Gent

Stoops G (2003) Guidelines for analysis and description of soil and regolith thin sections. Soil Science Society of America, Madison, WI, USA

Stoops G, Marcelino V, Mees F (2010) Interpretation of micromorphological features of soils and regoliths. Elsevier, Oxford

Stuiver M, Reimer PJ, Reimer R (2013) Calib radiocarbon calibration version 7.0.-http://calib.qub.ac.uk/calib/

Terhorst B, Ottner F (2003) Polycyclic luvisols in Northern Italy: paleopedological and clay mineralogical characteristics. Quatern Int 106-107:215-231

Valsecchi V, Tinner W, Finsinger W, Ammann B (2006) Human impact during the Bronze Age on the vegetation at Lago Lucone (northern Italy). Veg Hist Archaeobot 15:99-113

van Loon AJ (2006) Lost loesses. Earth Sci Rev 74:309-316

Viglino A, Capeder G (1898) Comunicazione preliminare sul loess piemontese. Boll Soc Geol Ital 17:81-84

Wacha L, Pavlakovic S, Novothny A, Crnjakovic M, Frechen M (2011) Luminescence dating of Upper Pleistocene loess from the Island of Susak in Croatia. Quatern Int 234:50-61

Waelbroeck C, Labeyrie L, Michel E, Duplessy CJ, McManus FJ, Lambeck K, Balbon E, Labracherie M (2002) Sea-level and deep water temperature changes derived from benthic foraminifera isotopic records. Quat Sci Rev 21:295-305

Wick L (1996) Late-glacial and early-Holocene palaeoenvironments in Brianza, N Italy. Il Quaternario 9:653-660

Wintle AG (1997) Luminescence dating: laboratory procedures and protocols. Radiat Meas 27:769-817 
WRB (2006) World reference base for soil resources 2006. World Soil Resources Reports 103. FAO, Rome

Zanchetta G, Drysdale RN, Hellstrom JC, Fallick AE, Isola I, Gagan MK, Pareschi MT (2007) Enhanced rainfall in the Western Mediterranean during deposition of sapropel S1: stalagmite evidence from Corchia cave (Central Italy). Quat Sci Rev 26:279-286

Zerboni A, Trombino L, Cremaschi M (2011) Micromorphological approach to polycyclic pedogenesis on the Messak Settafet plateau (central Sahara): formative processes and palaeoenvironmental significance. Geomorphology 125:319-335

Zhornyak LV, Zanchetta G, Drysdale RN, Hellstrom JC, Isola I, Regattieri E, Piccini L, Baneschi I, Couchoud I (2011) Stratigraphic evidence for a "pluvial phase" between ca 8200e7100 ka from Renella cave (Central Italy). Quat Sci Rev 30:409-417

Zorzi F (1959) Un'Amigdala Acheuleana scoperta a Lughezzano di Valpantena nel quadro del paleolitico inferiore e medio Veronese. Memorie del Museo Civico di Storia Naturale di Verona, vol. III 